Article

\title{
Production, Reserves, and Processing of Feldspar and Feldspathoid Rocks in the Czech Republic from 2005 to 2019-An Overview
}

\author{
Jan Zahradník ${ }^{1,2} \mathbb{0}$, Jakub Jirásek ${ }^{3, *}$, Jaromír Starý ${ }^{4}$ and Martin Sivek ${ }^{2}$ \\ 1 LB MINERALS, s.r.o., Tovární 431, 33012 Horní Bříza, Czech Republic; jan.zahradnik@cz.lasselsberger.com \\ 2 Department of Geological Engineering, Faculty of Mining and Geology, Vysoká Škola Báňská-Technical \\ University of Ostrava, 17. listopadu 15/2172, 70800 Ostrava-Poruba, Czech Republic; martin.sivek@vsb.cz \\ 3 Department of Geology, Faculty of Science, Palacký University Olomouc, 17. listopadu 1192/12, \\ 77146 Olomouc, Czech Republic \\ 4 Czech Geological Survey, Klárov 3, 11821 Praha, Czech Republic; jaromir.stary@geology.cz \\ * Correspondence: jakub.jirasek@upol.cz
}

Received: 5 July 2020; Accepted: 10 August 2020; Published: 17 August 2020

\begin{abstract}
This paper aims to characterize and interpret the trends in reserves, resources, and mine production of feldspar and feldspathoid rocks during 2005-2019 in the Czech Republic. With over $101 \mathrm{Mt}$ of total resources and $22 \mathrm{Mt}$ of reserves, feldspar belongs to the crucial industrial minerals of the Czech Republic. With annual outputs of approximately 400-450 kt of feldspars and 20-35 kt of feldspathoid rocks (nepheline syenite), the Czech Republic ranks among the top European and world feldspar producers. Most of the production comes from leucocratic granitoid rocks (key active deposit: Krásno-Vysoký Kámen), followed by sedimentary rocks (key active deposit: Halámky), and granitic pegmatites (key active deposit: Luženičky). Nepheline syenite is mined at a single deposit. All deposits are extracted from open pits (quarries). Ongoing geological prospecting and exploration for new deposits are increasing available reserves and resources. The feldspar raw materials are used in the domestic glass and ceramic industries, while more than $50 \%$ is exported, generally to Poland and Germany.
\end{abstract}

Keywords: feldspar; feldspathoid; mine production; reserves; resources; glass industry; ceramic industry; Czech Republic

\section{Introduction}

Minerals of the feldspar group are the most abundant minerals in the Earth's crust. They are common in most igneous rocks and frequently occur in metamorphic and arenaceous sedimentary rocks. Structurally, they belong to the tectosilicate group, where interlinked tetrahedra of $\mathrm{AlSi}_{3} \mathrm{O}_{8}$ form a 3D framework. The feldspars are subdivided into K- and Na-bearing (alkali) feldspars, a Ca-Na solid-solution series called plagioclases (Table 1), and rare feldspars containing barium, strontium, rubidium, and ammonium [1-5].

The industrial use of feldspar minerals is restricted to the most common varieties and those with low melting points, such as alkali feldspars (orthoclase and microcline) and Na-rich plagioclase (albite). Major consumers are the glassmaking and ceramic industries. In glassmaking, it is crucial because its alkali components reduce the melting temperature of quartz and help to control the viscosity of glass. In the ceramic industry it also serves as a fluxing agent during manufacturing of ceramic products such as sanitary ware, tableware, and tiles, and for the production of enamel frits [6-9]. The significant share goes to functional filler applications, such as into the paint, rubber [10-12] composites and 
polymers (plastics) [13-17], adhesive industry, and coatings [18]. Other uses are for example welding electrodes [19].

Considering mined feldspar production in 2018, the highest outputs are from Turkey (7500 kt), Italy $(3500 \mathrm{kt})$, India $(1500 \mathrm{kt})$, China $(2000 \mathrm{kt})$, and Thailand $(1500 \mathrm{kt})$. The figures for feldspar reserves are not given by some countries, such as China or Italy, but the largest reserves are reported in Egypt, Iran, and India [2].

Frequently, nepheline syenite, nepheline phonolite, and other plutonic and volcanic feldspathoid rocks are extracted as feldspar substitutes [20]. Feldspathoids (foids) are rock-forming minerals similar to feldspar but with smaller amounts of silica [1,21] (Table 1). They can be used for glassmaking, ceramics [22-24], fillers, and possibly as sources of potassium for fertilizers [25] in the same way as feldspar.

Table 1. Industrially used feldspars and feldspathoid minerals and their theoretical composition $[26,27]$.

\begin{tabular}{|c|c|c|c|c|c|c|}
\hline Mineral & Mineral Formula & $\mathrm{K}_{2} \mathrm{O}$ & $\mathrm{Na}_{2} \mathrm{O}$ & $\mathrm{CaO}$ & $\mathrm{Al}_{2} \mathrm{O}_{3}$ & $\mathrm{SiO}_{2}$ \\
\hline \multicolumn{7}{|l|}{ Alkali Feldspars } \\
\hline Orthoclase & $\mathrm{KAlSi}_{3} \mathrm{O}_{8}$ & 16.92 & 0 & 0 & 18.32 & 64.76 \\
\hline Microcline & $\mathrm{KAlSi}_{3} \mathrm{O}_{8}$ & 16.92 & 0 & 0 & 18.32 & 64.76 \\
\hline Albite & $\mathrm{NaAlSi}_{3} \mathrm{O}_{8}$ & 0 & 11.82 & 0 & 19.44 & 68.74 \\
\hline \multicolumn{7}{|l|}{ Plagioclase Series } \\
\hline Albite (endmember) & $\mathrm{NaAlSi}_{3} \mathrm{O}_{8}$ & 0 & 11.82 & 0 & 19.44 & 68.74 \\
\hline Oligoclase $^{1}$ & $(\mathrm{Na}, \mathrm{Ca})\left[\mathrm{Al}(\mathrm{Si}, \mathrm{Al}) \mathrm{Si}_{2} \mathrm{O}_{8}\right]$ & 0 & 9.34 & 4.23 & 23.05 & 63.38 \\
\hline Andesine ${ }^{1,2}$ & $(\mathrm{Na}, \mathrm{Ca})\left[\mathrm{Al}(\mathrm{Si}, \mathrm{Al}) \mathrm{Si}_{2} \mathrm{O}_{8}\right]$ & 0 & 6.92 & 8.35 & 26.57 & 58.16 \\
\hline Labradorite ${ }^{1,2}$ & $(\mathrm{Ca}, \mathrm{Na})\left[\mathrm{Al}(\mathrm{Al}, \mathrm{Si}) \mathrm{Si}_{2} \mathrm{O}_{8}\right]$ & 0 & 4.56 & 12.38 & 30.01 & 53.05 \\
\hline Bytownite ${ }^{1,2}$ & $(\mathrm{Ca}, \mathrm{Na})\left[\mathrm{Al}(\mathrm{Al}, \mathrm{Si}) \mathrm{Si}_{2} \mathrm{O}_{8}\right]$ & 0 & 2.25 & 16.31 & 33.37 & 48.07 \\
\hline Anorthite (endmember) ${ }^{2}$ & $\mathrm{CaAl}_{2} \mathrm{Si}_{2} \mathrm{O}_{8}$ & 0 & 0 & 19.20 & 35.84 & 44.40 \\
\hline \multicolumn{7}{|l|}{ Feldspathoids } \\
\hline Nepheline & $\mathrm{Na}_{3} \mathrm{~K}\left(\mathrm{Al}_{4} \mathrm{Si}_{4} \mathrm{O}_{16}\right)$ & 8.06 & 15.91 & 0 & 34.90 & 41.13 \\
\hline
\end{tabular}

1 Not considered an individual mineral species, but variety names with different molar ratios of albite and anorthite endmembers. ${ }^{2}$ Their industrial use is limited by their high Ca-content and/or scarcity in nature.

The traditional industrial sources of feldspars are granitic pegmatites and aplites [28]. With technological shifts, the attention of producers now also focuses on felsic granitic rocks such as alkali granites (e.g., [29,30]), acid effusive rocks, and associated tuffs [5], and on sedimentary accumulations of feldspar (e.g., [31,32]).

The Czech Republic is one of the most important feldspar producers and exporters. It ranks 10th in the world and 3rd among European producers if we consider Turkish production from mostly Asian parts of the country $[10,33]$. Feldspathoid rock is also produced in the country. This paper summarizes the resources, reserves, production, and processing of both feldspar and feldspathoid rocks in the Czech Republic over the last 15 years, i.e., between 2005 and 2019.

\section{Classification and Quality Criteria of Czech Feldspars}

Feldspars belong to the mineral commodities, which are not traded on a global level via exchanges, but rather on bilateral contracts between producers and consumers. Therefore, international classification of quality criteria is missing.

However, two sets of criteria are available for this mineral group. One of them is used by geologists, who utilize mineralogical composition of raw material, and therefore its chemical composition expressed as content of main oxides $\left(\mathrm{K}_{2} \mathrm{O}, \mathrm{Na}_{2} \mathrm{O}, \mathrm{CaO}, \mathrm{Al}_{2} \mathrm{O}_{3}\right.$, and $\left.\mathrm{SiO}_{2}\right)$, and the content of major undesirable impurities $\left(\mathrm{Fe}_{2} \mathrm{O}_{3}\right.$ and $\left.\mathrm{TiO}_{2}\right)$. The second approach is mostly used by treatment plans, which follows application properties set by final customers. Technologists of end customers are in direct contact with technologists of mining and processing organizations, where the result of mutual communication is the optimization of the production process and classification criteria for the needs of the customer. This is 
highly individual and private, but apart from the feldspar, alkali, and impurities content, the monitored parameters also include rheological properties, sintering curve, loss on ignition, firing color, etc.

In the territory of the Czech Republic, the former Czech Standard ČSN 721370 [34] described in later paragraphs is still used as primary classification criteria for prospecting companies.

Feldspar and feldspar raw materials are products of extraction with high contents of feldspar minerals. Feldspars in rocks consist of a mixture of feldspar minerals, which are divided into three basic groups. These are calcium feldspar (labeled $\mathrm{Ca}$ ), sodium feldspar ( $\mathrm{Na}$ ), and potassium feldspar (K). According to the dominant representation of individual minerals and hence elements found on the basis of silicate chemical analysis in samples, the basic classification of feldspar raw material is determined (Table 2).

Table 2. Czech classification of feldspars according to the ratio of main oxides.

\begin{tabular}{cccc}
\hline Feldspar & Label & $\mathbf{K}_{2} \mathbf{O} /\left(\mathbf{K}_{\mathbf{2}} \mathbf{O}+\mathbf{N a}_{\mathbf{2}} \mathbf{O}\right)$ & $\mathrm{CaO} /\left(\mathrm{CaO}+\mathrm{Na}_{2} \mathbf{O}-\mathbf{K}_{\mathbf{2}} \mathbf{O}\right)$ \\
\hline potassium & $\mathrm{K}$ & $0.75-1.00$ & \\
potassium-sodium & $\mathrm{KNa}$ & $0.60-0.75$ & \\
sodium-potassium & $\mathrm{NaK}$ & $0.40-0.60$ & \\
sodium & $\mathrm{Na}$ & $0.00-0.40$ & $0.16-0.63$ \\
sodium-calcium & $\mathrm{NaCa}$ & & $0.63-1.00$ \\
calcium-sodium & $\mathrm{CaNa}$ & & \\
\hline
\end{tabular}

The type of feldspar raw material, i.e., the division into $\mathrm{K}-\mathrm{Na}-\mathrm{Ca}$ feldspars is one of the most important pieces of information for the future use of raw materials. The content of the abovementioned cations determines the dominant technological properties, such as water absorption, firing temperature, shrinkage dependence on burning, and sintering curves.

The total content of feldspar substances in percentage terms according to the former Czech Standard ČSN 721370 [14] is determined as the total feldspar (" $\breve{Z}$ ") content of either potassium and

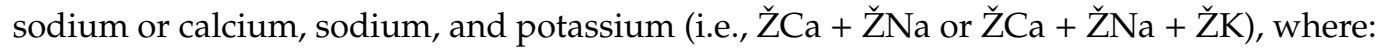

The potassium feldspar content, in \%, is calculated according to the formula:

$$
\check{\mathrm{ZK}}=\mathrm{K}_{2} \mathrm{O} \times 5.905
$$

The sodium feldspar content, in \%, is calculated according to the formula:

$$
\check{\mathrm{Z}} \mathrm{Na}=\mathrm{Na}_{2} \mathrm{O} \times 8.458
$$

And the calcium feldspar content, in \%, is calculated according to the formula:

$$
\check{\mathrm{Z}} \mathrm{Ca}=\mathrm{CaO} \times 4.961
$$

A very important parameter that indicates the quality of feldspar raw material is the content of $\mathrm{Fe}_{2} \mathrm{O}_{3}$. The content of iron-containing minerals is essentially due to the occurrence of iron-bearing minerals in rock fissures and to inclusions of mineral aggregates. With the increasing content of Ca-feldspars, the occurrence of iron minerals usually increases. The iron content is set at a maximum of $1 \%$, which is indicated on the label of produced feldspar.

The label of produced feldspar consists of the designation "Ž35-100", indicating the percentage of feldspar substance (35 to 100\% of feldspar content), followed by the composition of feldspar material "K; KNa; $\mathrm{NaK}, \mathrm{NaCa}$ " (Table 3). The label is completed with numerical evaluation of the $\mathrm{Fe}_{2} \mathrm{O}_{3}$ content given in hundredths of a percent.

For the ceramic and glass industries, it is important that either the content of iron-containing minerals is minimal or the iron is bound to minerals that are removable during treatment, e.g., by washing or mechanical separation. 
In cases where iron-containing minerals form inclusions within feldspar grains, more complicated treatment methods, such as micro-milling with subsequent electromagnetic separation, can be used in some cases.

A notable parameter that is not mentioned in the label of the product is the content of $\mathrm{TiO}_{2}$. The maximum limit for titanium dioxide content is set at $0.2 \%$ for feldspar with $\mathrm{Fe}_{2} \mathrm{O}_{3}$ content over $0.25 \%$ and at $0.1 \% \mathrm{TiO}_{2}$ for feldspars with $\mathrm{Fe}_{2} \mathrm{O}_{3}$ content below $0.25 \%$.

Table 3. Examples of labeling feldspar products according to the former Czech standard ČSN 721370 [34].

\begin{tabular}{|c|c|c|c|c|c|}
\hline Label & $\begin{array}{c}\text { Feldspar Content } \\
(\%)\end{array}$ & $\begin{array}{c}\mathrm{K}_{2} \mathrm{O} /\left(\mathrm{K}_{2} \mathrm{O}+\mathrm{Na}_{2} \mathrm{O}\right) \\
\text { Ratio }\end{array}$ & $\begin{array}{c}\mathrm{Fe}_{2} \mathrm{O}_{3} \max . \\
(\%)\end{array}$ & $\begin{array}{l}\mathrm{TiO}_{2} \max . \\
(\%)\end{array}$ & $\begin{array}{c}\text { Fused Material } \\
\text { Color }\end{array}$ \\
\hline Ž85K15 & 85 & $0.75-1.0$ & 0.15 & 0.1 & white \\
\hline Ž85KNa25 & 85 & $0.6-0.75$ & 0.25 & 0.1 & white \\
\hline Ž65NaK40 & 65 & $0.4-0.6$ & 0.40 & 0.2 & with shade \\
\hline Ž55K60 & 55 & $0.75-1.0$ & 0.60 & 0.2 & with shade \\
\hline Ž55KNa40 & 55 & $0.6-0.75$ & 0.40 & 0.2 & with shade \\
\hline Ž40Na100 & 40 & $0.0-0.4$ & 1.00 & 0.2 & with shade \\
\hline
\end{tabular}

\section{Czech Feldspar and Feldspathoid Rock Deposits, Their Extraction, Reserves, and Resources}

Feldspars are classified as "reserved" minerals by the Czech Mining Act [35]; i.e., their deposits are owned by the state. In the Czech Republic, there are a total of 41 deposits registered in the Balance of reserves of reserved minerals in the Czech Republic [36]. There are also predicted deposits that do not have sufficient geological surveys to reach reserve status in the category "prospected".

Feldspar deposits in the Czech Republic (Figure 1) can be divided according to their genesis, parent rock source, etc. The most commonly used division is according to the genetic types of rocks from which feldspar raw material is obtained, in combination with the regional-geological division.

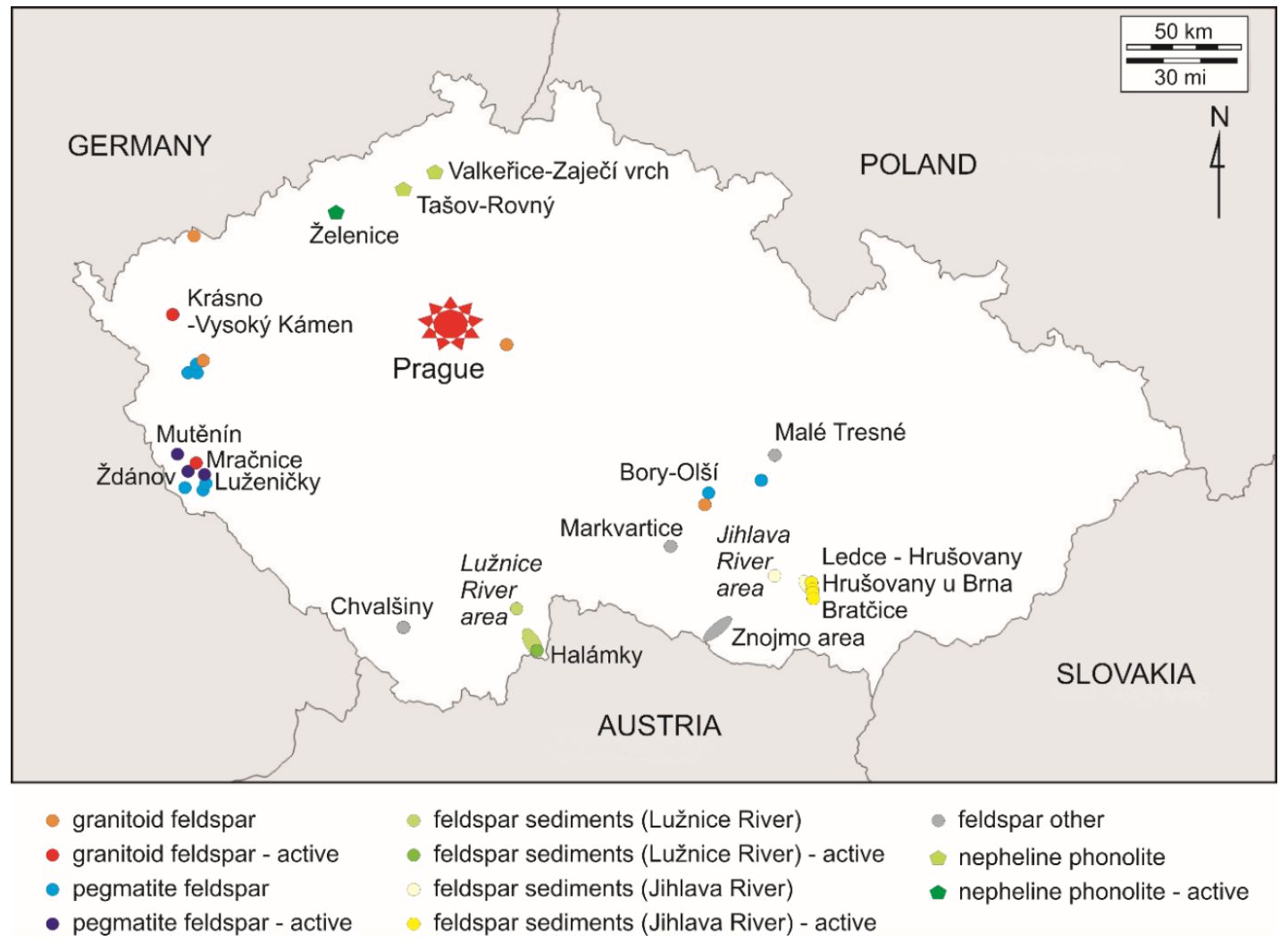

Figure 1. Locations of feldspar and feldspathoid rock deposits in the Czech Republic. 
In the Czech Republic, only magmatic and sedimentary deposits are extracted. Granitic pegmatites include 3 separate areas: Poběžovice-Domažlice in the southwestern part of the country, Teplá area in the western part of the country, and the West-Moravian area in the southeastern part of the country. The Luženičky, Ždánov, and Mutěnín deposits from the first area are only three pegmatites presently exploited, but just the Luženičky deposit reaches industrially significant production. Leucocratic granitoids include 5 registered deposits. Two of them are active (Krásno-Vysoký Kámen and Mračnice), but only the Krásno-Vysoký Kámen deposit reaches industrially significant production. The group of alluvial feldspar deposits includes the Lužnice River area with the important Halámky active deposit and sediments of the Jihlava River at the Syrovice-Ivaň and Ivančice terraces in Moravia with 8 registered deposits, of which four are exploited (mainly as sand and gravel for construction). Other types of feldspar deposits do not have industrial importance at this time, but some might have the potential for the future.

The simplified geological map is given in Figure2. Generally, the majority of magmatic and metamorphic feldspar deposits are connected with the Variscan Orogeny [37], i.e., they are of Carboniferous to Permian age. Exceptions are industrially important Quaternary feldspar gravels (Lužnice and Jihlava river areas) and rare residual occurrences connected to the Tertiary weathering (Znojmo area). All nepheline phonolites are of Tertiary age.

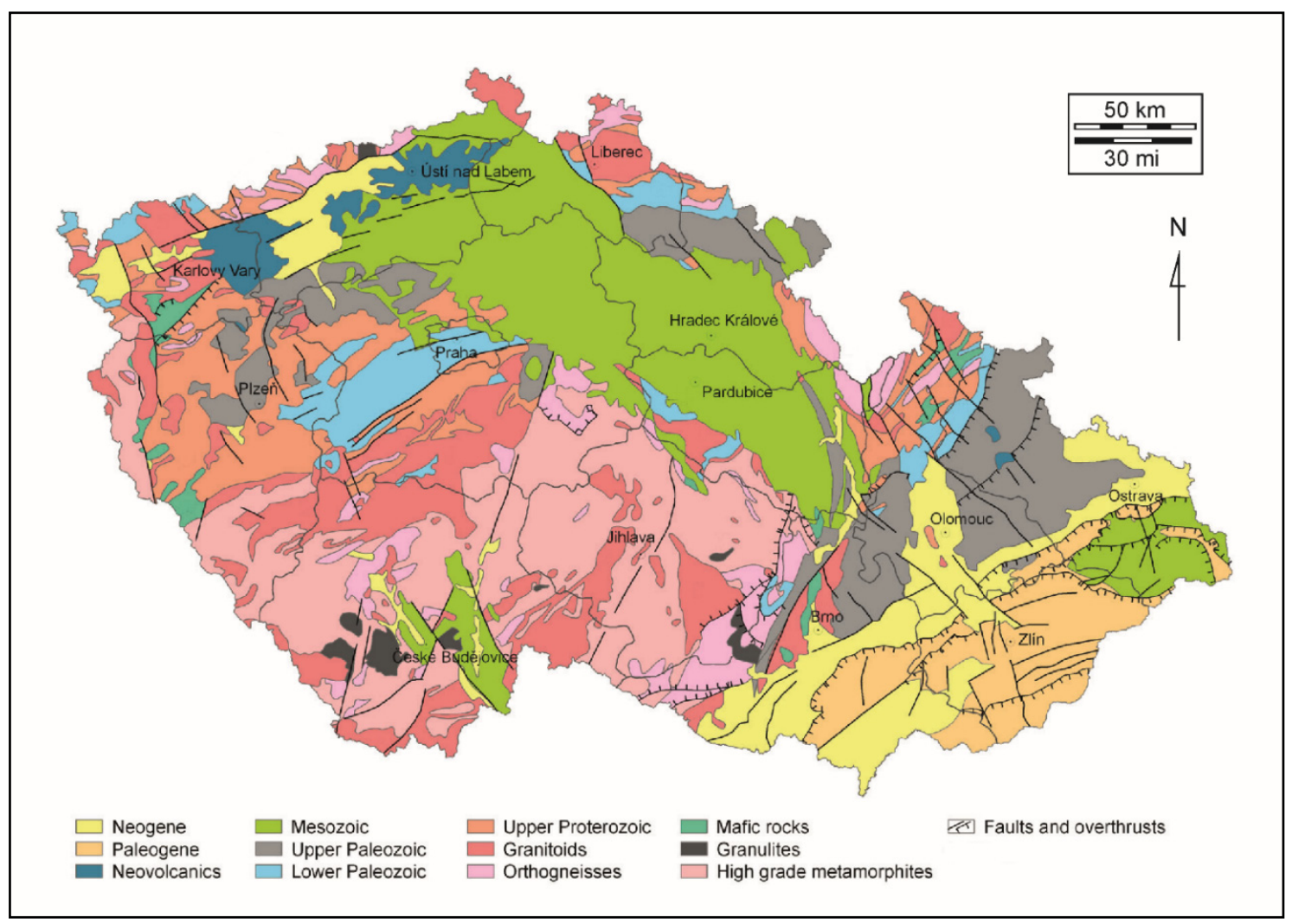

Figure 2. Simplified geological map the Czech Republic [38].

To help better understanding the production cycle of feldspar in the Czech Republic described in detail later, brief characteristics of quarrying techniques and processing in as follows: technology of feldspar mining in the Czech Republic is linked to the genetic types of used deposits. At the present time, two basic types of mining are used. In the first place, it is mining by an open pit (quarry) with the use of blasting and subsequent treatment by crushing, sorting, and grinding. In the case of alluvial (river sediment) deposits, it is the extraction of dry or wet gravel and the separation of the specific fraction to which the feldspar raw material is bound. Both cases could be followed by the 
electromagnetic separation. There are a total of 4 processing plants (mills) used for the processing and treatment of feldspar raw materials in operation in the Czech Republic.

Key data on Czech feldspar production are given in Table 4. The volume of resources, reserves, and mine production of individual deposits is not possible to release due to non-public data. To explain the terminology, "economic reserves" are those suitable for extraction under both existing technical and economic conditions. The categories "proved" and "probable" reserves divide the reserves according to exploitability conditions. "Potentially economic resources" are those currently unexploitable due to low grade, small amount, complicated extraction conditions, or problematic processing [38].

Table 4. Key data on feldspar in the Czech Republic [36,38-40].

\begin{tabular}{ccccccccc}
\hline Feldspar deposits & $\mathbf{2 0 0 5}$ & $\mathbf{2 0 0 6}$ & $\mathbf{2 0 0 7}$ & $\mathbf{2 0 0 8}$ & $\mathbf{2 0 0 9}$ & $\mathbf{2 0 1 0}$ & $\mathbf{2 0 1 1}$ & $\mathbf{2 0 1 2}$ \\
\hline Total number of deposits & 34 & 33 & 33 & 34 & 34 & 35 & 35 & 37 \\
Active deposits & 10 & 10 & 10 & 8 & 8 & 8 & 9 & 9 \\
Total mineral resources (kt) & 67,610 & 65,497 & 71,092 & 69,234 & 68,788 & 68,696 & 68,276 & 70,191 \\
Economic proved reserves (kt) & 24,979 & 24,518 & 30,126 & 28,594 & 28,176 & 27,784 & 27,392 & 26,574 \\
Economic probable reserves (kt) & 35,590 & 27,566 & 27,220 & 26,829 & 26,804 & 27,107 & 27,079 & 29,621 \\
Potentially economic resources (kt) & 7041 & 13,413 & 13,746 & 13,811 & 13,808 & 13,805 & 13,805 & 13,996 \\
Mineable reserves (kt) & 10,890 & 10,447 & 15,213 & 14,625 & 16,666 & 15,960 & 24,940 & 24,444 \\
Mine production (kt) & 472 & 487 & 514 & 488 & 431 & 388 & 407 & 445 \\
\hline Feldspar deposits & $\mathbf{2 0 1 3}$ & $\mathbf{2 0 1 4}$ & $\mathbf{2 0 1 5}$ & $\mathbf{2 0 1 6}$ & $\mathbf{2 0 1 7}$ & $\mathbf{2 0 1 8}$ & $\mathbf{2 0 1 9}$ \\
\hline Total number of deposits & 37 & 36 & 36 & 39 & 39 & 40 & 41 \\
Active deposits & 9 & 9 & 9 & 9 & 9 & 9 & 10 \\
Total mineral resources (kt) & 70,184 & 69,729 & 69,271 & 76,476 & 76,063 & 91,722 & 101,487 \\
Economic proved reserves (kt) & 25,889 & 25,456 & 25,048 & 24,593 & 24,415 & 28,709 & 29,742 \\
Economic probable reserves (kt) & 30,815 & 30,793 & 31,052 & 36,185 & 36,162 & 47,157 & 55,889 \\
Potentially economic resources (kt) & 13,480 & 13,480 & 13,171 & 15,698 & 15,698 & 15,856 & 15,856 \\
Mineable reserves (kt) & 24,299 & 23,887 & 28,041 & 22,981 & 22,872 & 22,596 & 22,126
\end{tabular}

Feldspathoid rocks represent 3 nepheline phonolites deposits in the northern and northwestern parts of the country (Figure 1); the Želenice is a single active deposit. During the investigated period, no prospecting work was carried out; generally, the exploitable (recoverable) reserves are slightly more than $24 \mathrm{Mt}$, and the economic probable reserves (total resources) are slightly less than $200 \mathrm{Mt}$. The average annual mine production is $24 \mathrm{kt}[36,38-40]$.

\section{Geological Situation of Czech Feldspar and Feldspathoid Deposits.}

Feldspar deposits are characterized by diverse origins and variable characteristics of the feldspar raw materials. Although feldspars are common rock-forming minerals, particularly high content of iron compounds disqualifies many rocks from possible uses. Magmatic deposits (felsic granitoids, granitic pegmatites, and aplites) and sedimentary (sand and gravel) deposits that are mined only in open pits (quarries) dominate domestic reserves, resources (Figure 3), and production (Figure 4). Metamorphosed feldspar deposits (felsic orthogneisses) are not exploited yet, but one of them is currently being prospected. The following text focuses on each of these individual genetic groups. 


\section{Mt}

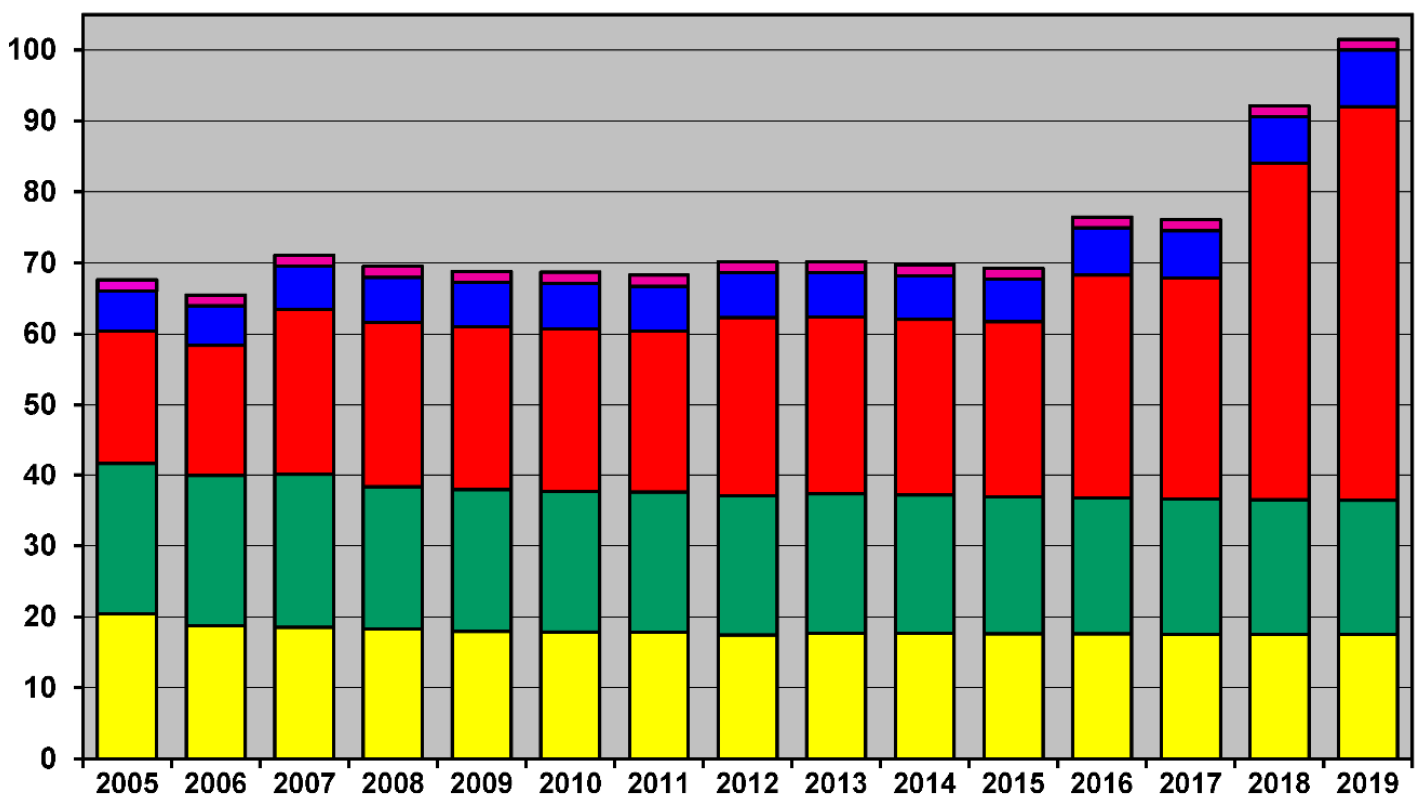

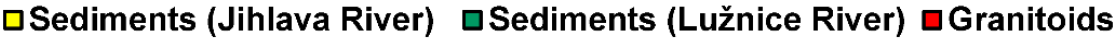

\section{口Pegmatites $\quad$ Metamorphic}

Figure 3. Total resources of the Czech feldspar deposit divided according to their geological types (modified after [36,38-40]).

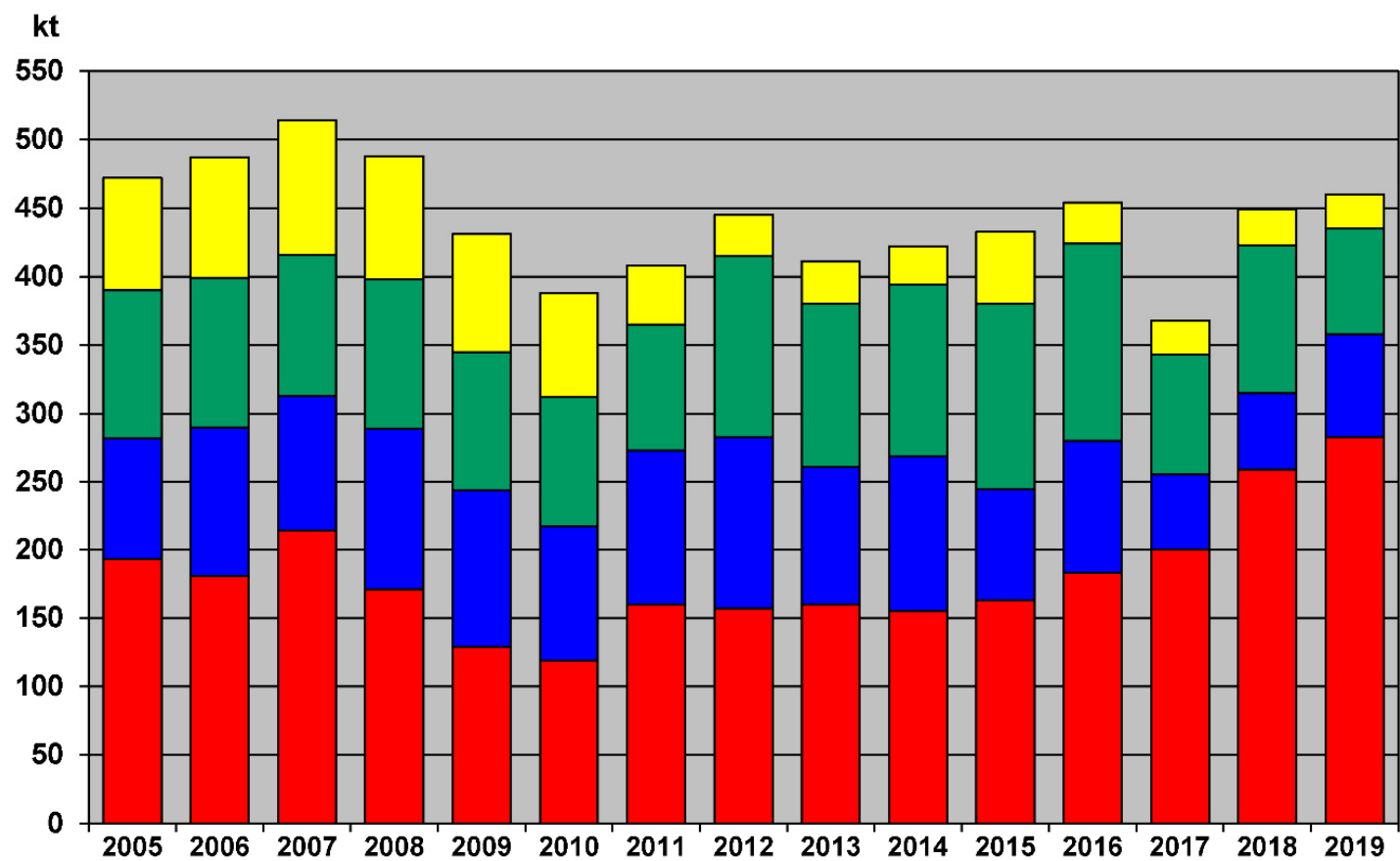

\section{$\square$ Granitoids $\quad$ Pegmatites $\square$ Sediments (Lužnice River) $\quad$ Sediments (Jihlava River)}

Figure 4. Mine production from different geological types of Czech feldspar deposits (modified after [36,38-40]). 


\subsection{Leucocratic Granitoids}

The Krásno-Vysoký Kámen deposit near Horní Slavkov in the Karlovy Vary Region is the main and the most significant representative of the granitoid type deposits (Figures 1 and 5). It represents an elevated erosional relict of a topaz-albite granitic stock, which belongs to the Karlovy Vary Pluton of Carboniferous age [37]. The part of the body that crops out has an oval shape and a size of approximately $600 \times 400 \mathrm{~m}$; it is surrounded by granite [41-43]. This principal granitoid type deposit was first recognized by geological mapping in 1948, and its extraction started in 1968 [44].

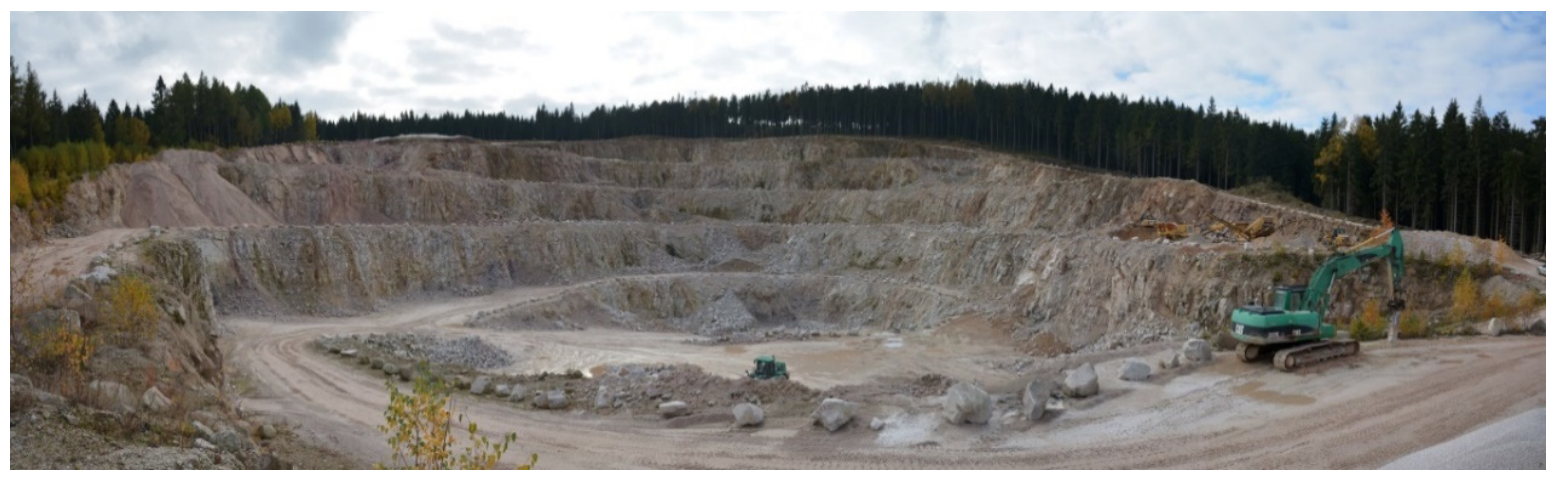

Figure 5. Krásno-Vysoký Kámen feldspar deposit: the most important magmatic deposit in the Czech Republic. Photo: Jaromír Starý, 2016.

The Vysoký Kámen stock is formed by leucocratic albite and topaz-albite granites. They are intersected by subhorizontal belts, veins, nests, and pipes of feldspar rocks described as aplogranite [41], feldspathite-albitite [42,43], and/or alkali feldspar syenite [45]. These rocks are accompanied by nests and irregular veins of granitic pegmatites. The main granitic facies have been described by various authors as aplogranites, albitites, and alkali feldspar syenites. These magmatic rocks show large-scale metasomatic albitization, K-feldspathization, and local greisenization [41,42].

The average content of feldspars varies between 55 and $85 \%$, with $\mathrm{Na}_{2} \mathrm{O}+\mathrm{K}_{2} \mathrm{O} 8.8 \%, \mathrm{Fe}_{2} \mathrm{O}_{3}$ $0.33-0.64 \%$, and $\mathrm{TiO}_{2}<0.1 \%$, but the specific parameters differ according to the rock type and extracted/prospected block [46]. The average quality of feldspar on the site of present mine is evaluated as Ž55NaK40-60. At greater depths, irregular feldspathite bodies with feldspar contents higher than $75 \%$ (equal content of albite and orthoclase) copy the course of contact with the underlying Li-bearing topaz granite. They can be characterized according to the national standard [34] as Ž85KNa25.

The raw material is treated on-site by crushing, grinding, and sorting to the final product, which is ground feldspar fraction $0-5 \mathrm{~mm}$. A permanent magnet is also installed in the treatment process to remove free Fe that has entered the raw material during processing. A product that corresponds to the label Ž60NaK40 (Ž55NaK60 in the sense of the former standard [34]) is shipped to customers and mainly used for ceramic and glass production.

Considering a yearly average from the last decade (2010-2019), the Krásno-Vysoký Kámen deposit production of $177 \mathrm{kt}$ ranks 1 st in domestic production with an $\sim 42 \%$ share. Its significance might become even greater in the near future due to its increasing trend, while other important deposits are approaching the ends of their lifespans. Due to its relatively high reserves and resources (cited in the last publicly available reserve estimation [44]), this deposit has enormous potential for feldspar mining for at least three decades into the future.

The Mračnice deposit can be considered a typical representative of leucocratic granitoids suitable as a source of feldspar raw material (Figure 1). It is situated in the Domažlice crystalline complex [47] as a part of a lens-shaped intrusion $4 \mathrm{~km}$ long and $1 \mathrm{~km}$ wide surrounded by metagraywackes, mica schists, and paragneisses. Granitoids of Cambrian age are classified as trondhjemite [48] or leucocratic quartz diorite [46]. In this intrusion, the Mračnice deposit is located between the villages of Mračnice and 
Němčice. The rock is whitish-gray and medium-grained. The dominant minerals are oligoclase and quartz. The average quality of feldspar has been evaluated as Ž55NaCa60 [49].

The raw material is transported to the processing plant Meclov, where it is ground and further treated by electromagnetic separation in order to reduce Fe-content.

The yearly average production from the last decade (2010-2019) was only $7 \mathrm{kt}$ because of the increasing content of calcium, which is not preferred by customers.

\subsection{Granitic Pegmatites}

Granitic pegmatites are coarse-grained rocks accompanying larger magmatic bodies. Their bodies usually have veined characteristics with thicknesses from centimeters to tens and rarely hundreds of meters (e.g., [50]). The largest pegmatite body extracted in the past in the Czech Republic was the Oldřich dike in the Dolní Bory-Hatě pegmatite district, which was $630 \mathrm{~m}$ long and up to $30 \mathrm{~m}$ thick, dipped $55-40^{\circ}$, and was extracted along a vertical distance of $140 \mathrm{~m}$. The largest reserves $(275 \mathrm{kt}$ in the block zone) and extraction (205 kt) were reported from vein No. 4 in the same district [51]. Pegmatites have been a crucial source of feldspars in past centuries.

At present, of the 16 registered granitic pegmatites deposits registered in state publications nine are located within the Poběžovice-Domažlice pegmatite district, four in the Teplá district, and two in the West-Moravia district. Extraction takes place only in three deposits located in the first area mentioned, which as situated in the Domažlice crystalline complex near the contact of the Moldabnubian and Teplá-Barrandian zones [47] in the southwestern part of the country. This pegmatite district has been productive at least since the 19th century [52].

The most important pegmatite deposit Luženičky is located near village of the same name (Figures 1 and 6) on the northern slope of Baldov Hill. It consists of a large pegmatite vein with an average thickness of $45 \mathrm{~m}$ and a length of $490 \mathrm{~m}$, dipping to the SE. It has been exploited since 1989, but small-scale underground mining took place in the first half of the 20th century [46].

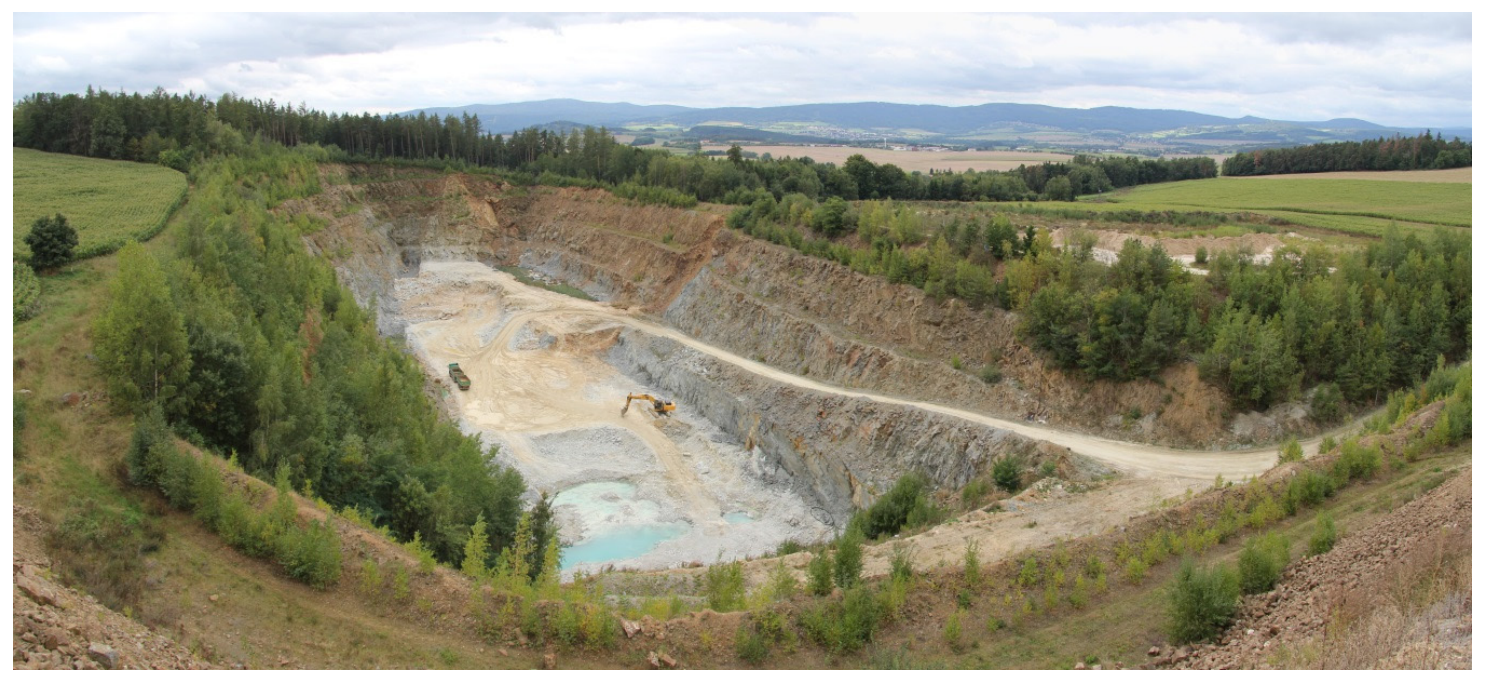

Figure 6. Luženičky feldspar deposit: a granitic pegmatite dike surrounded by paragneisses. Photo: Jaromír Starý, 2019.

The feldspar raw material in the deposit is bound to pegmatite, which is represented by very coarse- to coarse-grained rock with a significant predominance of feldspars over quartz, muscovite, and biotite. Microcline is typically altered to albite due to strong Na metasomatism. The average quality of feldspar on the site is evaluated as Ž55NaK40-60 [46,53,54].

The raw material is transported to the processing plants Meclov and Poběžovice, where it is ground and further treated by electromagnetic separation in order to reduce Fe-content. 
The deposit is mined in an open pit. The extraction of both overburden and the raw material itself is carried out by large- and small-scale blasting operations. The overburden of the pegmatite vein formed by the paragneiss is mined in advance, after which the cleared pegmatite vein is extracted.

Considering annual averages from the last decade (2010-2019), the Luženičky deposit production of $86 \mathrm{kt}$ ranks 3rd in domestic production, with a share of $20 \%$. However, there has been a long-term decline in production due to the poor availability of reserves, which might be reversed in the near future by ongoing exploration in the deeper part of the pegmatite dike and its northern continuation. The lifespan of the deposit, which was relatively short, has been extended by approximately 10 years due to new prospecting works [55].

The Ždánov pegmatite feldspar deposit (Figure 1) is situated between Ždánov and Pařezov villages. It consists of a coarse-grained mushroom-shaped pegmatite body hosted in leucocratic quartz diorite near the contact with gabbroid rocks. The prevailing minerals are oligoclase $(70-90 \%)$, K-feldspar (3-5\%), quartz (5-20\%), muscovite (2-3\%), and biotite (1-2\%). The quality of the feldspar raw material has been evaluated as Ž85NaCa40 [46].

The raw material is transported to the processing plants Meclov and Poběžovice, where it is ground and further treated by electromagnetic separation to reduce Fe-content to the label Ž85NaCa20.

The yearly average production from the last decade (2010-2019) was only 6 kt because of the increasing content of calcium, which is not preferred by customers.

At the Mutěnín pegmatite feldspar deposit (Figure 1), prospecting work was finished in 2019, and production is just beginning. Two pegmatite bodies are hosted in biotite-hornblende diorite. The quality of the feldspar raw material has been evaluated as Ž55NaK60 [56].

\subsection{Granitic Aplite}

Aplites are fine-grained felsic vein rocks with compositions mostly similar to granites. These rocks usually form thin veins inside granitoid bodies that are often accompanied by pegmatites, into which they can pass. The dominant group of aplites arises from escaping residues of solidifying granitoids that do not contain large amounts of volatile and incompatible substances [28].

The former prospect of feldspar from aplitic rocks Dvorec u Třebče has been under prospection and converted to the deposit. It is formed by leucocratic aplitic granites and orthogneisses. Aplitic fine-grained granite forms an evident vein body, occasionally passing into coarse-grained pegmatite parts [57].

\subsection{Unconsolidated Sediments—Feldspar Gravel}

An important source of feldspar raw materials are feldspar grains and fragments of feldspar rich rocks found in the sediments of recent and Quaternary rivers. Such alluvial feldspar deposits are recorded in two regionally important rivers: the Lužnice River in South Bohemia (5 registered deposits, with 1 of them extracted) and the Jihlava River in South Moravia (8 registered deposits, with 4 of them extracted). The paleochannels of these rivers contain all registered sedimentary deposits of feldspar gravel.

The Halámky deposit (Figures 1 and 7) is the most important alluvial (sand and gravel) type feldspar deposit in the Czech Republic. It consists of Quaternary sediments in the valley of the Lužnice River from the state border with Austria to the village of Halámky [46]. Deposits along the Lužnice River are also developed in the southern direction in neighboring Austria and follow the river flow to the north towards Třeboň town. In the valley, a system of river terraces originated in the Mindel to Würm glacial stages (of the Alps). The main accumulation of feldspar gravels is linked to the river paleochannel [58]. Extraction of feldspar sand and gravel takes place in an open pit with parallel progress of the mining walls. At the quarry, dry extraction is carried out by mining in the wall using a front-wheel loader and extraction from water by means of a suction dredger at the depth of the mining wall under water as deep as $25 \mathrm{~m}$. The average quality of feldspar in the fraction larger than $4 \mathrm{~mm}$ is Ž66K45 [58]. 


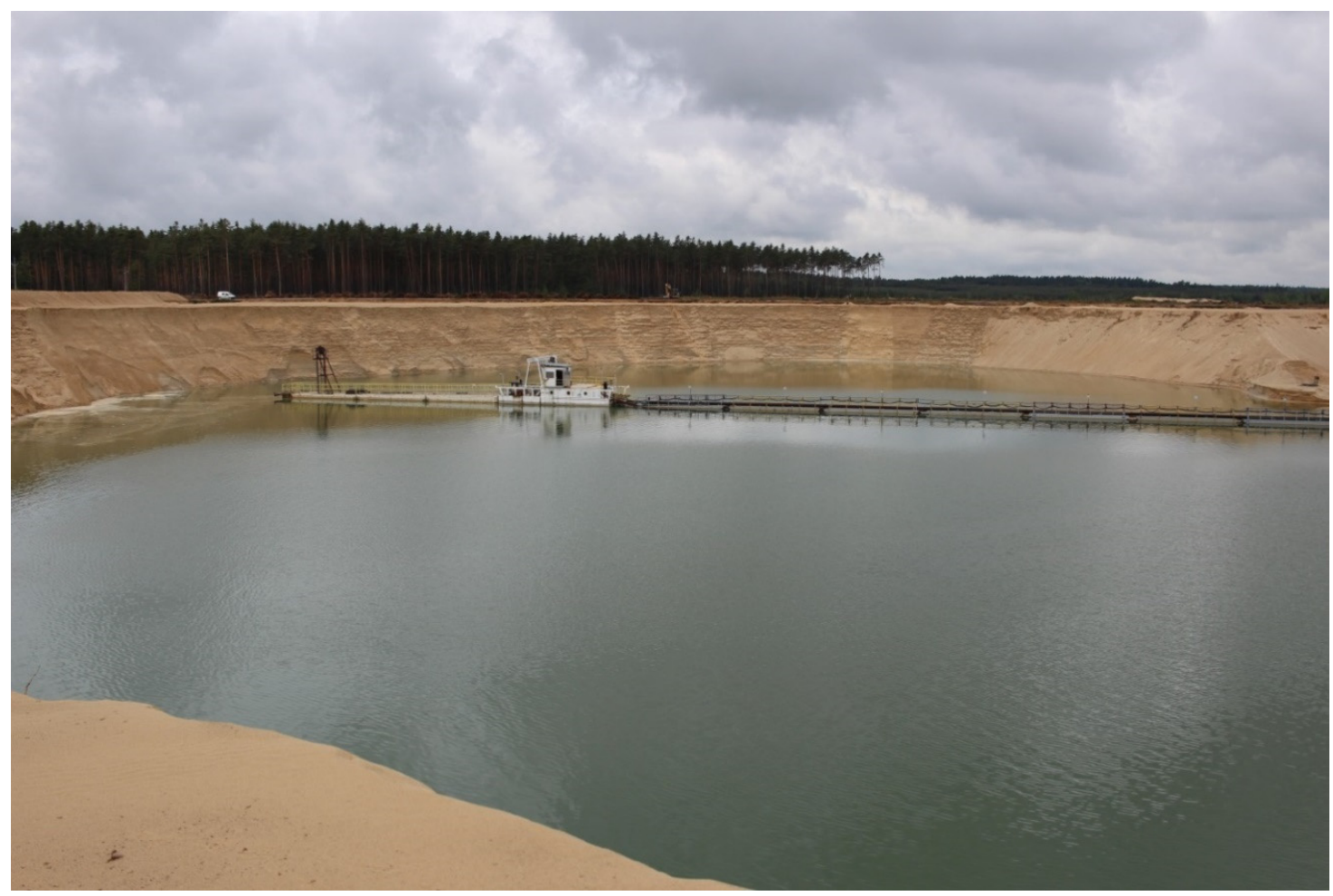

Figure 7. Halámky feldspar deposit: underwater extraction by a suction dredger. Photo: Jakub Jirásek, 2019.

The raw material is processed on-site by sorting into individual fractions and transported by the conveyor further to the Dobrá Voda treatment plant. There it undergoes electromagnetic separation in order to reduce biotite to quality label Ž75K15. It also produces feldspars of quality classes Ž40K20, Ž50K20, Ž65K20, and Ž75K20. The products are used mainly in the ceramic and glass industry as a flux.

Considering annual averages from the last decade (2010-2019), the Halámky deposit production of $111 \mathrm{kt}$ ranks 2 nd in domestic production, with a share of $\sim 26 \%$. The currently estimated lifespan of the reserves is $\sim 10$ years.

Unfortunately, the sediments of the Jihlava River do not contain high-quality feldspar raw materials that could be easily used in the ceramic or glass industry. The mine production of feldspars from the Syrovice-Ivan terrace is rather low. The local raw material represents feldspar gravel with a fraction of 4-8 mm with $\mathrm{Fe}_{2} \mathrm{O}_{3}$ up to $1 \%$ and minimum content of feldspar minerals of $55 \%$ [59]. The high $\mathrm{Fe}_{2} \mathrm{O}_{3}$ content limits its use in the ceramic and glass industries. The local deposits are mainly focused on the extraction of gravel, where feldspar raw material in a certain fraction is considered an accompanying raw mineral.

A registered deposit of feldspar raw materials and gravel and sand that could serve as a representative example is Ledce-Hrušovany $\mathrm{u}$ Brna (Figures 1 and 8), which lies in the northern part of the Quaternary (Pleistocene, Günz to Mindel) Syrovice-Ivaň terrace [60]. The whole deposit is located in the central zone of the terrace in the river paleochannel. The basement of the deposit is formed by Neogene sand.

Three horizons are distinguished within the deposit, which differs in thickness, petrographic composition, and economic importance. From top to bottom, these horizons are red-brown clay feldspar gravel, feldspar sands and gravel, and basal gravel. On the major part of the deposit surface (especially in the west and south), the so-called Main Clay Intercalation is developed at the base of feldspar sands and gravel. Feldspars are concentrated in the granulometric portion with sizes of $1-8 \mathrm{~mm}$ and contain $0.7 \% \mathrm{Fe}_{2} \mathrm{O}_{3}[46,59]$. The use of feldspar raw material from this deposit, as well as 
from surrounding deposits, is quite limited, and there is no demand for this material from the ceramic or glass industry.

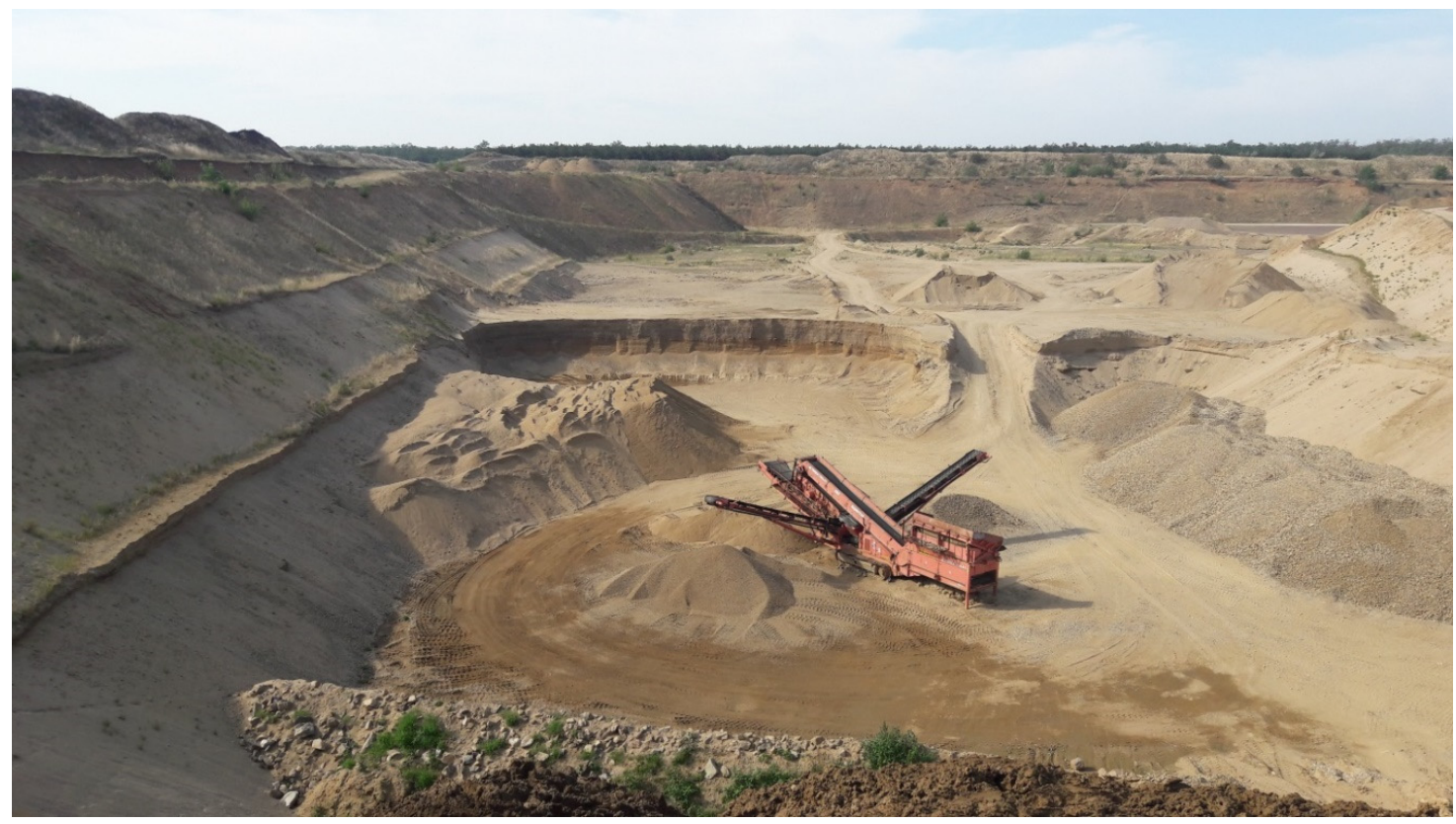

Figure 8. Sand and gravel pit Ledce-Hrušovany u Brna. Photo: Courtesy LB MINERALS, s.r.o., 2018.

The yearly average from the last decade (2010-2019) for all four extracted deposits (Bratčice, Hrušovany u Brna, Hrušovany u Brna-Protlas, and Ledce-Hrušovany $u$ Brna) situated within the Syrovice-Ivaň terrace of the Jihlava River is $37 \mathrm{kt}$, which means a share of $\sim 9 \%$ of domestic production. Local feldspar raw material from all active deposits is only sorted and sold in a raw state to end customers.

\subsection{Unconsolidated Sediments-Residual Kaolin}

In the vicinity of the Únanov village in the Znojmo region (Figure 1), there are registered deposits of kaolin formed by weathering of granitoid rocks [61]. The process of kaolinization proceeds from the surface to depth; thus, there is also kaolin with a higher content of unaltered feldspars. Kaolin was extracted and used for the ceramic and paper industries in the past. During its mining, the Únanov-Tvořihráz deposit was considered a source of feldspar-bearing kaolin raw material because the waste after the kaolin processing is a material rich in feldspar grains [46]. The present potential of these deposits is uncertain, and their evaluation would require further geological prospecting.

\subsection{Consolidated Sediments-Arkoses}

To date, these rocks are only considered a possible source of feldspar raw material. Feldspar grains contained in sedimentary rocks of Carboniferous age may potentially be suitable for feldspar raw material recovery. The potential of such deposits is limited by the degree of alteration. Only rocks with incomplete kaolinization of feldspar grains would be suitable for potential use. The Tymákov deposit is one of the possible sources of feldspar-bearing arkose [62]. The degree of kaolinization is uneven here, and without further geological prospecting, whether it could be truly considered a feldspar raw material source cannot be established with certainty.

\subsection{Metamorphic Rocks-Leucocratic Gneiss, Charnockite, Albitite}

Three registered but unexploited Czech deposits classified as "others" in fact belong to this category of metamorphic rocks. 
The feldspatite gneiss to feldspatite Markvartice deposit is located in the southern part of the country (Figure 1), near the town of Třebíč. It is situated in the Moldanubian zone. The genesis of these potassium rocks is not clear. Some authors have described them as metasomatic rocks and some, as alkali feldspar syenites or leptynites [63-66]. The deposit forms an equidimensional body approximately $160 \times 180 \mathrm{~m}$ in extent, and the rock appears aplitic and is formed almost exclusively of orthoclase. It contains more than $1 \mathrm{Mt}$ of feldspar raw material with an average of $13.1 \mathrm{~K}_{2} \mathrm{O}$. After dry magnetic separation, it is labeled Ž85K60 [67].

The Chvalšiny deposit is located in the southern part of the country (Figure 1), near Český Krumlov town. It is situated in the Gföhl assemblage of the Moldanubian zone, namely, in the peripheral part of the Blanský less granulite massif $[68,69]$. At the edge of granulites, there is a belt of paragneisses including bodies of marbles and amphibolites. The feldspar deposit is composed of Ca-feldspar-rich granofels rock originally labeled anorthosite [70], which might be part of the charnockite series. It contains 70-80\% plagioclase $\mathrm{An}_{75-90}, 10-20 \%$ minerals from the amphibole supergroup, and $<5 \%$ apatite. Due to its high content of $\mathrm{CaO}$, it is considered suitable for casting powder production for the refractory industry. However, the exploitation has not started due to limited resources (106 kt) of this small podiform deposit and conflicts of interest with a local nature protection area [70].

The metamorphic Malé Tresné albitite deposit was recognized during prospecting for graphite in 1965. It is located in the central part of the country (Figure 1), near the town of Bystřice nad Pernštejnem. It is situated in the Svratka dome of the Moravicum unit. The contact between the Olešnice Group and the mica schist zone with a complicated geological setting contains four larger irregular pods of albitites enclosed in other metamorphic rocks. The rock is felsic and composed of predominantly albite and quartz, with accessory K-feldspar, muscovite, zircon, apatite, and rutile. The quality has been estimated between $\check{Z} 55 \mathrm{Na} 40$ and $\check{Z} 65 \mathrm{Na} 60$, with $\mathrm{Fe}_{2} \mathrm{O}_{3}$ at $0.4 \%$ and $\mathrm{TiO}_{2}$ at $0.06 \%$; after processing, this may be modified to Ž85Na40. Total resources have been estimated at $415 \mathrm{kt} \mathrm{[71,72].}$

Recently, the attention of feldspar prospects has been focused on the possibility of using leucocratic orthogneiss at the Dvorec u Třebče deposit, located in the district of České Budějovice. This deposit has already been mentioned in Section 4.2 due to the occurrence of aplite veins intersecting the surrounding leucocratic gneisses. These gneisses consist predominantly of quartz and feldspar with an average $\mathrm{K}_{2} \mathrm{O}+\mathrm{Na}_{2} \mathrm{O}$ of approximately $8 \%$ [57]. Such a high alkali content represents an interesting potential for extraction.

\subsection{Feldspathoid Rocks—Nepheline Phonolites}

Among feldspathoid rocks, nepheline syenites are commonly used as substitutes for feldspar minerals. However, their occurrences in the Czech territory are very limited, so the more common nepheline phonolites are taken into account. Since the 1950s, nepheline phonolites and trachytes have been considered potential substitutes for bauxite in alumina production [73,74]. During the geological prospecting, it was recognized that some of them have high $\mathrm{Na}_{2} \mathrm{O}+\mathrm{K}_{2} \mathrm{O}$ contents $(9.23-16.30 \%)$ that make ideal fluxes for certain types of ceramics. The high $\mathrm{Fe}_{2} \mathrm{O}_{3}$ content (up to $2 \%$ ) prevents their use in glassmaking and white ceramics. New prospecting works were carried out between 1985 and 1989 [75].

All three registered nepheline phonolite deposits are linked to Cenozoic volcanism in the České středohoři Mountains [76]. The only exposed deposit, Želenice-Želenický vrch (Figure 1), has been worked since the beginning of the 20th century for crushed stone [77]. It is an open-pit quarry at the foot of the hill (Figure 9). The content of alkalis is $16.3 \%$ with $\mathrm{Na}_{2} \mathrm{O}: \mathrm{K}_{2} \mathrm{O}$ of $\sim 2: 1, \mathrm{Al}_{2} \mathrm{O}_{3}$ is $22.4 \%$, and $\mathrm{Fe}_{2} \mathrm{O}_{3}$ is $1.8 \%$, with a homogenous distribution in the intrusive body $[75,78]$. 


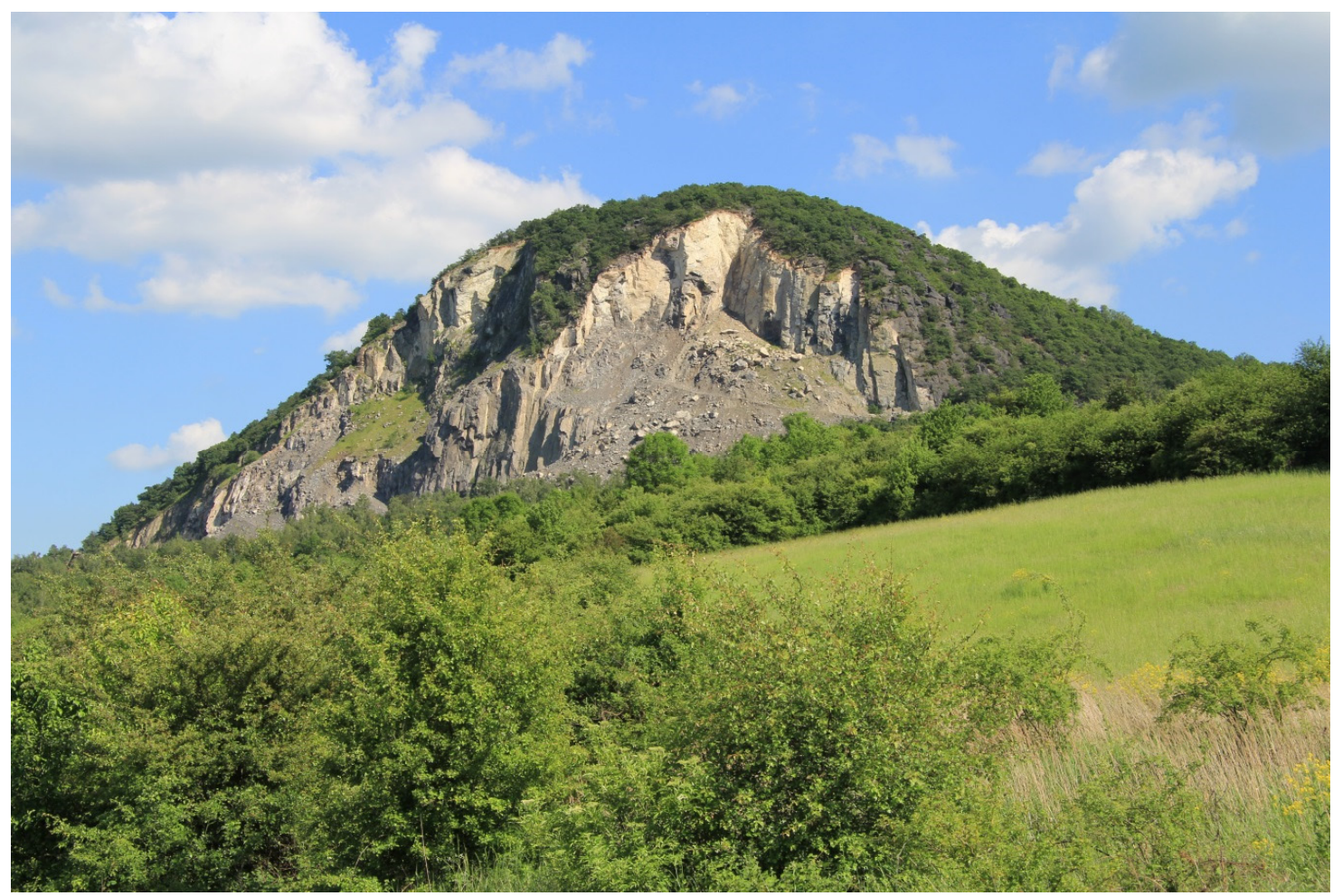

Figure 9. Želenice-Želenický vrch with nepheline phonolite deposit and quarry. Photo: Jaromír Starý, 2014.

\section{Use of Czech Feldspar and Feldspathoid Rocks}

The use of feldspar raw materials is to some extent limited by their mineralogical and chemical compositions. The main technological features of feldspar raw materials are the lowering of the melting temperature (e.g., flux) of a glass batch and the lowering of the sintering temperature or its stabilization in the production of ceramic material. Other uses, such as fillers and expanders in plastics, paints, and rubber, are also important.

Traditionally, feldspars with high potassium contents are preferred in the ceramics and glass industries due to their lower melting temperatures. Sources of potassium-rich feldspars include granitic pegmatites with orthoclase or microcline and some granitic rocks and arkoses.

Potassium feldspars are, due to their composition, the most sought-after raw material for the glass and ceramic industries (merged to KNa-feldspar category in Figure 10). They are widely used for the production of container and sheet glass, glazes, and porcelain. They are also used for the production of tiles, sintered tiles, sanitary ware, porcelain, electroporcelain, enamels, and frits.

The Halámky deposit is the most important source of this raw material. To achieve a higher quality of the final product, raw materials obtained by exploitation from water and sorting on the Halámky line are further treated. Subsequent dry grinding and multistage screening are prerequisites for final electromagnetic separation to remove unwanted iron-containing minerals.

Potassium-sodium feldspars are another logical type of feldspar raw material used in the ceramic and glass industries (merged to KNa-feldspar category in Figure 10). Currently, there is great interest in this raw material in these industries. This is to a certain extent due to mining at the Krásno-Vysoký Kámen deposit with large reserves, which can offer long-term stable production. The uses of this raw material are similar to those of the previous raw materials.

Sodium-potassium feldspars are probably the most widely used at present due to their versatility and availability (merged to KNa-feldspar category in Figure 10). They are logical substitutes for $\mathrm{K}$-feldspars in the ceramic and glass industries, where the potassium component is associated with 
typical and sought-after technological properties. Sodium-potassium feldspars are used as fluxes throughout the ceramic industry.

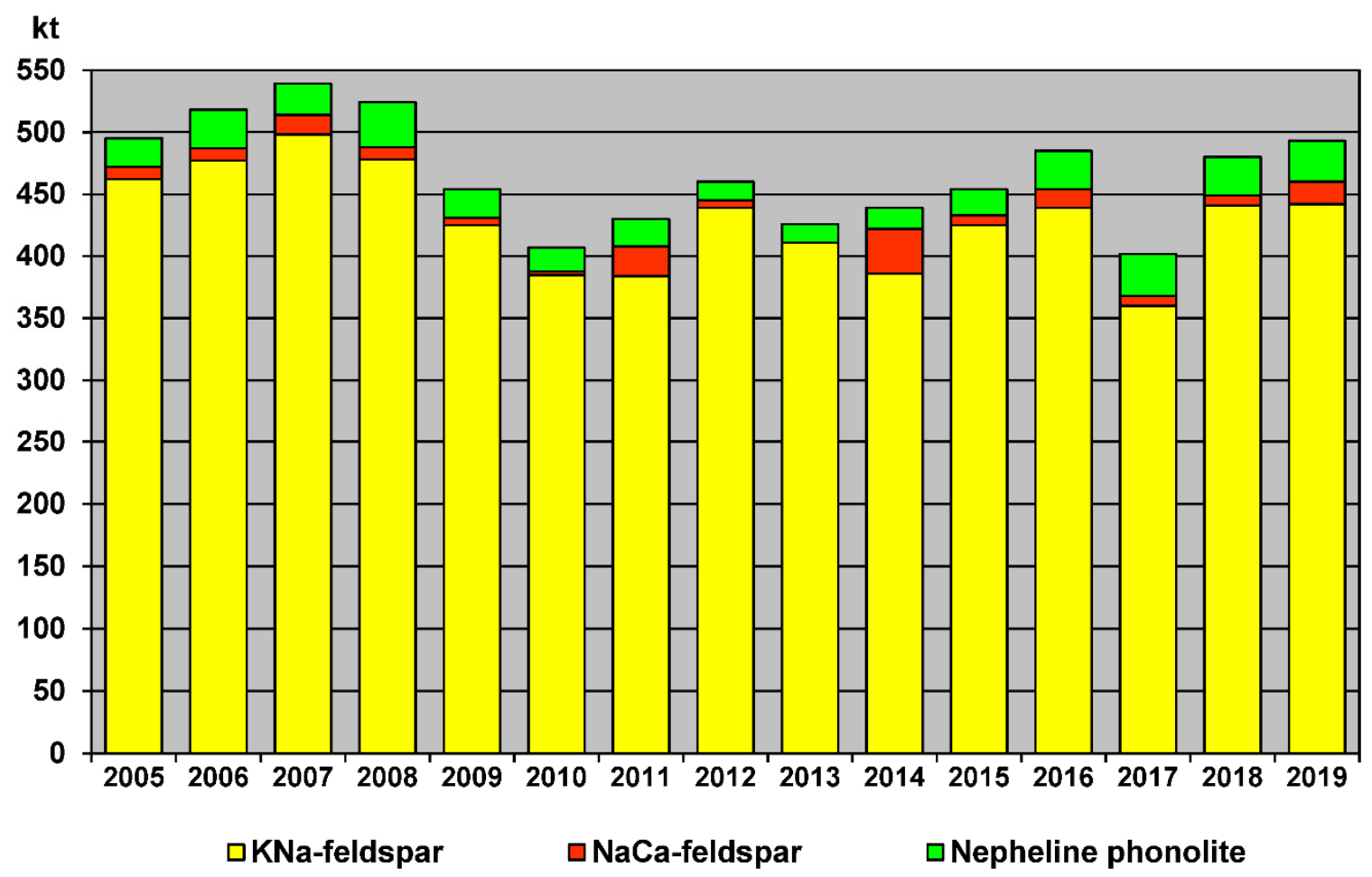

Figure 10. Czech mine production of different feldspar types.

To increase the utilization potential of this raw material, appropriate treatment is frequently used. The necessary properties of the products are achieved by appropriate mixing of individual feldspar raw materials, sometimes from several different deposits, and their subsequent crushing and dry grinding. The final finishing process is a multistage sorting of grist.

The use of sodium-calcium feldspars is very limited (Figure 10), and their domestic use in the ceramic and glass industries has not yet occurred. However, this material is sought in the production of frits and enamels, which are only a small part of the ceramic industry. For its possible widespread use in the glass industry, it is important to consider the composition of the ceramic batch from the view of additives to supply the missing $\mathrm{K}_{2} \mathrm{O}$.

Nepheline phonolites are produced (Figure 10) for the glass and ceramic industries in those applications where the content of $\mathrm{Fe}_{2} \mathrm{O}_{3}$ and $\mathrm{TiO}_{2}$ is not crucial, e.g., for the production of brown and brown-green bottle glass.

More than $50 \%$ of the annual feldspar production is exported. The main exports ( $80 \%)$ go to Poland, followed by Germany, Hungary, Slovakia, Austria, and Russia (Figure 11). 


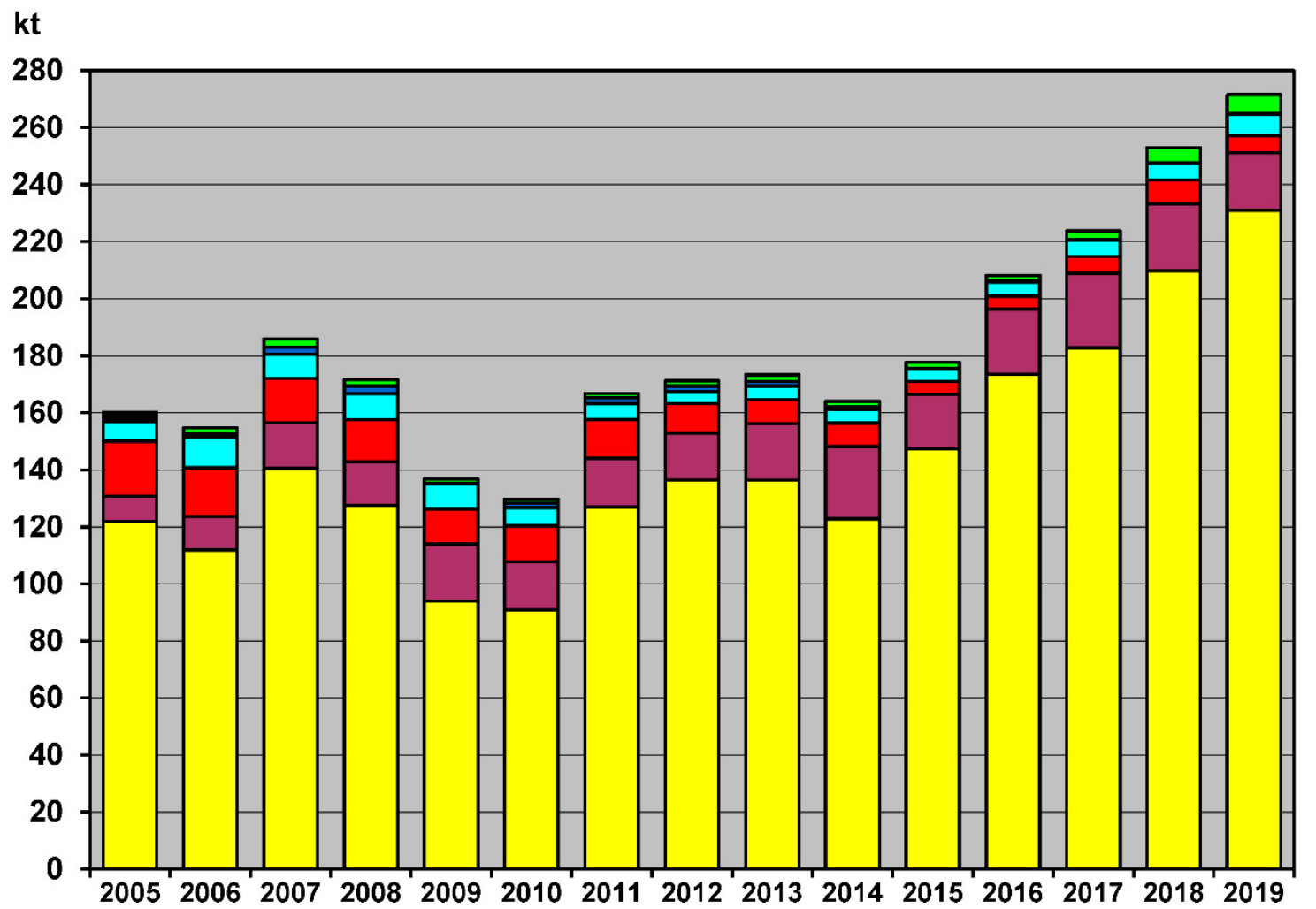

$\square$ Poland $\square$ Germany $\square$ Hungary $\square$ Slovakia austria $\square$ Russia $\square$ Others

Figure 11. Distribution of Czech feldspar exports.

\section{Discussion}

For hundreds of years, feldspars have been one of the industrial minerals extracted and used in the territory of the Czech Republic. The mine production of feldspars is quite variable and ranges between 368 and $514 \mathrm{kt}$ per year, with an average of approximately $440 \mathrm{kt}$ in the last 15 years. Therefore, the country ranks 9th worldwide and 4th within Europe. After 1999, feldspar mine production steadily increased until 2007 (cf. [33]), when it stabilized at the level of 400 to $450 \mathrm{kt}$ per year. This production does not focus primarily on the domestic industry but rather on exports to neighboring countries.

The extraction of nepheline rocks as feldspar substitutes is less important. Mine production varies between 15 and $36 \mathrm{kt}$ of nepheline phonolite per year, with an average of $25 \mathrm{kt}$ in the last 20 years. It is impossible to rank this output on a global scale since the exact figures of production, reserves, and resources for such mineral raw materials are not published by most countries.

The uses of produced feldspar and nepheline rocks are limited by the mineralogical and therefore chemical composition. The main consumers are the glass and ceramic industries, where the demand focuses on potassium-rich feldspars. In the future, we can expect a growing tendency towards the use of potassium-rich feldspars with an increased content of sodium. This shift will also be accompanied by the need to mix raw materials from different deposits and the need for better mineral processing, especially the increasing of feldspar content and reduction of coloring oxides $\left(\mathrm{Fe}_{2} \mathrm{O}_{3}, \mathrm{TiO}_{2}\right)$ in the feldspar products. On the other hand, the use of sodium-potassium feldspars is still limited to some frits and enamel, which constitute only a minor part of the ceramic industry.

The expected lifespan of some Czech feldspar deposits exceeds one hundred years due to very large reserves $(22 \mathrm{Mt})$ and total resources $(101 \mathrm{Mt})$. As new prospecting and development works are carried out, the available reserves and resources could be even increased. The main long-term trends are the increasing significance of granitic-type deposits and the gradual decrease in the importance 
of pegmatite-type deposits. Active large deposits with high-quality feldspar raw material, mainly sedimentary and pegmatite types, are gradually exhausted and do not have adequate substitution. Reserve deposits of these types are largely smaller, or they dispose with raw material of lower quality, and often are also blocked by conflicts of interests. The Krásno-Vysoký Kámen as a key domestic exploited feldspar deposit of granitic type has sufficient reserves, but the other deposits of this type have a significantly lower quality of the feldspar raw material. The future of the Czech feldspar depends on the use of modern and sophisticated processing methods, so the quality of the produced feldspar would remain high and consistent even if the initial raw material is of a lower quality.

Domestic feldspar production is also supported by the new Czech mineral policy, which understands feldspar as traditionally extracted mineral, the production of which should be promoted [79].

Considering future developments in the Czech feldspar industry, some trends can be seen. For the upcoming decades, the crucial consumers will still remain glass and ceramic industries, where feldspars and feldspathoids reduce energy intensity and in fact do not have reasonable substitutes.

For production, a stable situation is expected, unless new demand arises. The existing mine capacities are close to the maximum levels and their production is covered by long-term contracts. In the case of feldspar raw material treatment, mining and processing plants strive to improve the quality of the final products, both by optimizing mining technologies and by improving raw material treatment processes. In mining technologies, the modern technologies are tested, or at least the mining mechanisms are modernized. The treatment plants are currently testing technology to optimize grinding processes and the energy intensity of the treatment process, which would enable a decrease in costs.

\section{Conclusions}

With over $101 \mathrm{Mt}$ of total resources and $22 \mathrm{Mt}$ of reserves, feldspar belongs to the crucial industrial minerals of the Czech Republic. With annual outputs of approximately 400-450 kt of feldspars and 20-35 kt of feldspathoid rocks (nepheline syenite), the Czech Republic ranks among the top European and world feldspar producers. Most of the production comes from leucocratic granitoid rocks, followed by sedimentary rocks, and granitic pegmatites. Nepheline syenite is mined at a single deposit. All deposits are extracted from open pits (quarries). The processing is rather simple: at some deposits, it comprises only of crushing, grinding, and sorting, at others from grounding and electromagnetic separation. Ongoing geological prospecting and exploration for new deposits are increasing available reserves and resources, although there might be a shortcoming of high grade $\mathrm{K}$ and Na-feldspars due to a shift in producing deposit types in the future. The feldspar raw materials are used in the domestic glass and ceramic industries, while more than $50 \%$ is exported, generally to Poland and Germany.

Relatively large Czech feldspar production is of great importance for Central European areas. Considering neighboring countries, feldspars are produced in Germany, Poland, Austria, and Slovakia. German production reached $253 \mathrm{kt}$ in 2018 and $285 \mathrm{kt}$ when "pegmatite sand" is included [80]. In Poland, three operating feldspar deposits produced $72 \mathrm{kt}$ of raw material in 2018 [81]. A significant amount of granite fractions as the granite crushed aggregate by-product is also used as a flux in the ceramic industry, despite the high content of coloring oxides [82]. Polish prospects for new deposits are mentioned by [83-85]. Feldspar production in Austria has maintained a level of $\sim 35 \mathrm{kt}$ per year during the last five years [86]. Slovakia has 21.8 Mt of feldspars (total reserves) in eight deposits, of which only one is currently exploited. However, the extracted amounts from the Rudník II deposit do not exceed $8 \mathrm{kt}[87]$.

Author Contributions: Conceptualization, J.Z. and J.J.; methodology, J.Z., J.J., J.S. and M.S.; formal analysis, J.Z., J.J. and J.S.; investigation, J.Z., J.J., J.S. and M.S.; resources, J.Z., J.J. and J.S.; writing-original draft preparation, J.Z., J.J. and J.S.; writing-review and editing, J.J., J.S. and M.S.; supervision, J.J. and M.S.; validation, J.S.; funding acquisition, J.Z. and M.S. All authors have read and agreed to the published version of the manuscript. 
Funding: This research was supported by "Ministry of Education, Youth, and Sports of the Czech Republic, grant numbers SP2020/79".

Conflicts of Interest: The authors declare no conflict of interest with the exception of Jan Zahradník, who is employed by the LB Minerals s.r.o. company, one of the Czech feldspar producers. The funders had no role in the design of the study; in the collection, analyses, or interpretation of data; in the writing of the manuscript, or in the decision to publish the results.

\section{References}

1. Deer, W.A.; Howie, R.A.; Zussman, J. An Introduction to The Rock-Forming Minerals, 3rd ed.; Mineralogical Society of Great Britain \& Ireland: London, NY, USA, 2013; 541p. [CrossRef]

2. Smith, J.V.; Brown, W.L. Feldspar Minerals. Volume 1: Crystal Structures, Physical, Chemical and Microstructural Properties, 2nd ed.; Springer: Berlin/Heidelberg, Germay, 1988; 828p. [CrossRef]

3. Smith, J.V. Feldspar Minerals. Volume 2: Chemical and Textural Properties; Springer: Berlin, Germay, 1974; 691p. [CrossRef]

4. Ribbe, P.H. (Ed.) Feldspar Mineralogy: Volume 2, 2nd ed.; Reviews in Mineralogy; Mineralogical Society of America: Chantilly, VA, USA, 1983; 362p.

5. Van Der Plas, L. Chapter 2: The nature of feldspars. In Developments in Sedimentology; Elsevier Publishing Company: Amsterdam, The Netherland, 1966; Volume 6, pp. 19-40. [CrossRef]

6. Bernasconi, A.; Marinoni, N.; Pavese, A.; Francescon, F.; Young, K. Feldspar and firing cycle effects on the evolution of sanitary-ware vitreous body. Ceram. Int. 2014, 40, 6389-6398. [CrossRef]

7. Lee, W.E.; Iqbal, Y. Influence of mixing on mullite formation in porcelain. J. Eur. Ceram. Soc. 2001, 21, 2583-2586. [CrossRef]

8. Martin-Marquez, J.; Rincon, J.M.; Romero, M. Mullite development on firing in porcelain stoneware bodies. J. Eur. Ceram. Soc. 2010, 30, 1599-1607. [CrossRef]

9. Kara, A.; Özer, F.; Kağan, K.; Özer, P. Development of a multipurpose tile body: Phase and microstructural development. J. Eur. Ceram. Soc. 2006, 26, 3769-3782. [CrossRef]

10. Ghalayini, Z.T. Feldspar and nepheline syenite. In Mineral Commodity Summaries 2020; U.S. Geological Survey: Reston, VA, USA, 2020; pp. 58-59. [CrossRef]

11. Ismail, H.; Osman, H.; Ariffin, A. A comparative study on curing characteristics, mechanical properties, swelling behavior, thermal stability, and morphology of feldspar and silica in SMR L vulcanizates. Polym. Plast. Technol. 2005, 43, 1323-1344. [CrossRef]

12. Ismail, H.; Osman, H.; Ariffin, A. Curing characteristics, fatigue and hysteresis behaviour of feldspar filled natural rubber vulcanizates. Polym. Plast. Technol. 2007, 46, 579-584. [CrossRef]

13. Ansari, M.N.M.; Ismail, H.; Zein, S.H.S. Effect of multi-walled carbon nanotubes on mechanical properties of feldspar filled polypropylene composites. J. Reinf. Plast. Comp. 2009, 28, 2473-2485. [CrossRef]

14. Razak, J.A.; Akil, H.M.; Ong, H.L. Effect of inorganic fillers on the flamability behavior of polypropylene composites. J. Thermoplast. Compos. 2007, 20, 195-205. [CrossRef]

15. Mansour, S.H.; Asaad, J.N.; Ebd-El-Messieh, S.L. Synthesis and characterization of brominated polyester composites. J. Appl. Polym. Sci. 2006, 102, 1356-1365. [CrossRef]

16. Raszewski, Z.; Nowakowska-Toporowska, A.; Weżgowiec, J.; Nowakowska, D.; Więckiewicz, W. Influence of silanized silica and silanized feldspar addition on the mechanical behavior of polymethyl methacrylate resin denture teeth. J. Prosthet. Dent. 2020, 123, 647 e1-647 e7. [CrossRef]

17. Zilles, J.U. Feldspar and syenites. In Fillers for Polymer Applications. Polymers and Polymerics Composites: A Reference Series; Springer: Cham, Switzerland, 2017; pp. 231-244. [CrossRef]

18. Kouloumbi, N.; Ghivalos, L.G.; Pantazopoulou, P. Determination of the performance of epoxy coatings containing feldspars fillers. Pigm. Resin Technol. 2005, 34, 148-153. [CrossRef]

19. Zhang, Y.; Hu, Y.; Sun, N.; Liu, R.; Wang, Z.; Wang, L.; Sun, W. Systematic review of feldspar benefication and its comprehensive application. Miner. Eng. 2018, 128, 141-152. [CrossRef]

20. Kangal, M.O.; Bulut, G.; Yesilyurt, Z.; Basturkcu, H.; Burat, F. Characterization and production of Turkish nepheline syenites for industrial applications. Physicochem. Probl. Mi. 2019, 55, 605-616. [CrossRef]

21. Hassan, I. Feldspathoids and their relationship to zeolites. Kuwait J. Sci. Eng. 1997, 24, 163-183.

22. Krivenko, P.; Petropavlovskii, O.; Vozniuk, H. Alkaline aluminosilicate-based adhesives for concrete and ceramic tiles. Rev. Rom. Mat. 2016, 46, 419-423. 
23. Pavlunenko, L.E. Feldspar materials in Ukraine. Glass Ceram+. 2010, 67, 216-219. [CrossRef]

24. Deshkar, A.; Marcial, J.; Southern, S.A.; Kobera, L.; Bryce, D.L.; McCloy, J.S.; Goel, A. Understanding the structural origin iof crystalline phase transformations in nepheline $\left(\mathrm{NaAlSiO}_{4}\right)$-based glass-ceramics. J. Am. Ceram. Soc. 2017, 100, 2859-2878. [CrossRef]

25. Manning, D.A.C. Mineral sources of potassium for plant nutrition. A review. Agron. Sustain. Dev. 2010, 30, 281-294. [CrossRef]

26. Anthony, J.W.; Bideaux, R.A.; Bladh, K.W.; Nichols, M.C. Handbook of Mineralogy: Volume II, Part 2, 2nd ed.; Mineral Data Publishing: Tuscon, AZ, USA, 1995; pp. 1-458.

27. Hålenius, U.; Hatert, F.; Pasero, M.; Mills, S.J. New minerals and nomenclature modifications approved in 2018. Mineral. Mag. 2018, 82, 445-451. [CrossRef]

28. Dill, H.G. Pegmatites and aplites: Their genetic and applied ore geology. Ore Geol. Rev. 2015, 69, 417-561. [CrossRef]

29. Lee, G.F.; Stitt, P.H. The Oberon alaskite deposit a source of beneficated feldspar. J. Aust. Ceram. Soc. 1982, $18,49-52$.

30. Taboada, J.; Vaamonde, A.; Saavedra, A.; Ordonez, C. Geostatistical study of the feldspar content and quality of a granite deposit. Eng. Geol. 2002, 65, 285-292. [CrossRef]

31. Klyachin, V.V.; Gabdulkhaev, R.L.; Voronin, L.P.; Stepanova, M.V. Use of coarse-crystalline potassium feldspar from kaolin deposits. Glass Ceram+. 1978, 35, 413-415. [CrossRef]

32. Pavlunenko, L.E. Alkali kaolins of Ukraine-Complex raw materials for the ceramics industry. Glass Ceram+. 2010, 67, 190-192. [CrossRef]

33. Starý, J.; Kavina, P. Czech feldspar. Ind. Miner. 2005, 10, 48-53.

34. ČSN 72 1370. Czechoslovak National Standard: Feldspars and Feldspar Raw Materials; Approved in May 17, 1988, active since July 1, 1989; Úřad pro normalizaci a měření: Praha, Czechoslovak Socialist Republic, 1988; 7p. (In Czech)

35. Act No. 44 of 19 April 1988 On Mineral Protection and Use (the Mining Act); Federal Assembly of the Czechoslovak Socialist Republic: Praha, Czechoslovak Socialist Republic, 1988; 14p. (In Czech)

36. Starý, J.; Novák, J.; Mojžíš, J.; Novák ml., J. Bilance zásob výhradních ložisek nerostů České republiky k 1. lednu 2020 Díl III.: Výhradní Ložiska Nerudních Surovin; Ministerstvo životního prostřední České republiky \& Česká geologická služba: Praha, Czech Republic, 2020; 235p. (In Czech)

37. Cháb, J.; Breiter, K. Variscan and early post-Variscan intrusions. In Outline of the Geology of the Bohemian Massif: The Basement Rock and Their Carboniferous and Permian Cover; Cháb, J., Ed.; Czech Geological Survey Publishing House: Prague, Czech Republic, 2010; pp. 187-213.

38. Starý, J.; Sitenský, I.; Mašek, D.; Hodková, T.; Vaněček, M.; Novák, J.; Kavina, P. Mineral commodity summaries of the Czech Republic 2019; Czech Geological Survey: Prague, Czech Republic, 2019; 394p.

39. Starý, J.; Kavina, P.; Vaněček, M.; Sitenský, I.; Kotková, J.; Hodková, T. Mineral Commodity Summaries of the Czech Republic 2010; Czech Geological Survey Geofond: Prague, Czech Republic, 2010; 518p.

40. Starý, J.; Sitenský, I.; Mašek, D.; Hodková, T.; Vaněček, M.; Novák, J.; Horáková, A.; Kavina, P. Mineral Commodity Summaries of the Czech Republic 2015; Czech Geological Survey: Prague, Czech Republic, 2015; 412p.

41. Fiala, F.; Pácal, Z. Aplogranit albitowy z Krasna na tle surowców skaleniowych Czechosłowacji. Biul. Inst. Geol. 1968, 223, 119-154. (In Polish)

42. Pácal, Z.; Pavlů, D. Nové poznatky o ložisku sodno-draselných živců Vysoký kámen u Krásna. Geol. pri̊zk. 1972, 14, 357-360. (In Czech)

43. Jarchovský, T. The nature and genesis of greisen stocks at Krásno, Slavkovský les area western Bohemia, Czech Republic. J. Czech Geol. Soc. 2006, 51, 201-216. [CrossRef]

44. Punčochář, M.; Hron, M.; Kottnauer, R. Krásno Ložiskový Pri̊zkum 2006, Závěrečná zpráva; Unpublished; GIS Geoindustry, s.r.o.: Praha, Czech Republic, 2007; 53p. (In Czech)

45. Dolníček, Z.; René, M. Evidence for activity of low-temperature Ca-Na-Cl brines in feldspathitized granites of the feldspar deposit near Krásno (Krudum granite body). Geol. výzk. Mor. Slez. 2012, 19, 137-140. (In Czech with English summary) [CrossRef]

46. Belej, C.; Bufka, J.; Duda, J.; Hájek, M.; Kužvart, M.; Mátl, V.; Nosek, P. Živec. In Ložiska nerudních surovin ČR II; Kužvart, M., Ed.; Univerzita Karlova: Praha, Czech Republic, 1992; pp. 56-83. (In Czech) 
47. Vejnar, Z.; Doležal, J.; Hazdrová, M.; Kř́ž, J.; Mrňa, F.; Pokorný, L.; Rudolský, J.; Šefrna, L.; Tásler, R.; Tomášek, M.; et al. Geology of the Domažlice Region; Academia: Praha, Czech Republic, 1984; 234p. (In Czech with English Summary)

48. Zulauf, G.; Dörr, W.; Fiala, J.; Vejnar, Z. Late Cadomian crustal tilting and Cambrian transtension in the Teplá-Barrandian unit (Bohamian Massif, Central European Variscides). Geol. Rundsch. 1997, 86, 571-584. [CrossRef]

49. Čtyroký, V.; Hřibal, Z.; Macourek, K.; Nosek, P. Závěrečná zpráva geologického úkolu: Mračnice, suroviny: žula; Unpublished; Geoindustria, n.p.: Praha, Czech Republic, 1963; 37p. (In Czech)

50. London, D.; Kontak, D.J. Granitic pegmatites: Scientific wonders and economic bonanzas. Elements 2012, 8 , 257-261. [CrossRef]

51. Duda, J. Pegmatites in the Bory granulite massif (Pegmatity v borském granulitovém masívu). Sbor. Geol. Věd $\check{R}$. LGaM 1986, 27, 157-202. (In Czech with English summary)

52. Vejnar, Z. (1965): Pegmatity poběžovicko-domažlické oblasti. Sbor. Geol. Věd. ̌̌. LG 1965, 4, 7-84. (In Czech with German summary)

53. Peikerová, S. Závěrečná zpráva geologického úkolu: Přepočet zásob na ložisku Luženičky; Unpublished; Gekon spol. s r.o.: Praha, Czech Republic, 2007; 19p. (In Czech)

54. Jarková, S. Závěrečná zpráva geologického úkolu: Luženičky severovýchod; Unpublished; Gekon s.r.o.: Praha, Czech Republic, 2012; 20p. (In Czech)

55. Jarková, S.; Pachl, V.; Zahradník, J. Závěrečná zpráva geologického úkolu: Přepočet zásob v DP Luženičky, surovina: živec, živcová surovina; Unpublished; Gekon, s.r.o.: Plzen, Czech Republic, 2019; 32p. (In Czech)

56. Ševčík, J.; Buriánek, D.; Jarková, S.; Pachl, V.; Ševčík, J.; Vybíral, J.; Wintrová, V. Závěrečná zpráva geologického úkolu Mutěnín, surovina: živec; Unpublished; Gekon, s.r.o.: Plzen, Czech Republic, 2009; 15p. (In Czech)

57. Hora, Z.; Morysek, A.; Čtyroký, V.; Milický, V.; Jindřich, J. Závěrečná zpráva geologického úkolu: Dvorec 513317 010; Unpublished; Geologický průzkum, n.p.: Praha, Czech Republic, 1965; 37p. (In Czech)

58. Jarková, S.; Zahradník, J. Závěrečná zpráva geologického úkolu: Halámky Přepočet zásob 2017; Unpublished; Gekon s.r.o.: Plzen, Czech Republic, 2018; 32p. (In Czech)

59. Opekar, L.; Brož, B.; Jaček, M.; Vrána, O. Závěrečná zpráva geologického úkolu: Přepočet zásob živcové suroviny a štěrkopisku na výhradním ložisku Ledce Hrušovany u Brna (B 3220 300) dle nových podmínek využitelnosti z prosince 2011; Unpublished; GET, s.r.o.: Praha, Czech Republic, 2015; 74p. (In Czech)

60. Zeman, A. Současný stav výzkumů pleistocenních fluviálních sedimentů v Dyjskosvrateckém úvalu a jejich problematika. Stud. Geogr. (Brno) 1974, 36, 41-60. (In Czech)

61. Starý, J.; Pticen, F.; Jirásek, J.; Sivek, M. Development of kaolin production, reserves and processing in the Czech Republic in 1999-2015. Gospod. Surowcami Min. 2017, 33, 121-142. [CrossRef]

62. Wild, J.; Pecka, I.; Knapp, R.; Stanislav, J.; Mašek, J. Závěrečná zpráva geologického úkolu: Prüzkum živcových arkos. Tymákov; Unpublished; Geologický průzkum, n.p.: Praha, Czech Republic, 1962; 37p. (In Czech)

63. Hranáč, P. Závěrečná zpráva: Netradiční suroviny v metalurgii; Unpublished; GEOMIN: Jihlava, Czech Republic, 2000; 11p. (In Czech)

64. Houzar, S. The alkali-feldspar syenite from Markvartice near Třebíč. Acta Mus. Moraviae, Sci. nat. 1986, 71, 221-222.

65. Houzar, S.; Šrein, V. Calcite-andradite microclinite from Markvartice near Třebíč, Western Moravia. Acta Mus. Moraviae Sci. nat. 1990, 75, 29-40.

66. Němec, D. Identification of rocks of leptite formation in Western Moravia. Acta Mus. Moraviae Sci. Nat. 1992, $77,41-47$.

67. Dosbaba, M.; Hájek, J.; Hranáč, P. Závěrečná zpráva: Draselné živce západní Moravy; Unpublished; GEOMIN: Jihlava, Czech Republic, 2010; 42p. (In Czech)

68. Franěk, J.; Schulmann, K.; Lexa, O. Kinematic and rheological model of exhumation of high pressure granulites in the Variscan orogenic root: Example of the Blanský les granulite, Bohemian Massif, Czech Republic. Mineral. Petrol. 2006, 86, 253-276. [CrossRef]

69. Janoušek, V.; Krenn, E.; Finger, F.; Míková, J.; Frýda, J. Hyperpotassic granulites from the Blanský les Massif (Moldanubian Zone, Bohemian Massif) revisited. J. Geosci. 2007, 52, 73-112. [CrossRef]

70. Šourek, J.; Hájek, J.; Grym, V.; Štrouf, R.; Pekárek, L.; Zápalka, D. Závěrečná zpráva úkolu Chvalšiny živec; Unpublished; Geoindustria GMS, s.p.: Jihlava, Czech Republic, 1992; 31p. (In Czech) 
71. Hranáč, P. Závěrečná zpráva Netradiční suroviny v metalurgii, dílči úkol Malé Tresné, čislo úkolu 74812311, surovina: Na-živec, stav ke dni 31.5.1996; Unpublished; GEOMIN s.r.o.: Jihlava, Czech Republic, 1996; 15p. (In Czech)

72. Hranáč, P.; Pticen, F. Závěrečná Zpráva: Ověření Technologických Vlastností Na-živců v tělesech Albititů Olešnické Skupiny Moravika; Unpublished; GEOMIN s.r.o.: Jihlava, Czech Republic, 2012; 30p. (In Czech)

73. Čada, M.; Franče, J.; Knapp, R. Závěrečná zpráva úkolu Nebauxitové hlinikové suroviny; Unpublished; Geoindustria: Praha, Czech Republic, 1980; 39p. (In Czech)

74. Jiránek, J. Možnosti použití fonolitů a trachytů Českého masívu. In Ložiska Nerudních Surovin ČR II.; Kužvart, M., Ed.; Univerzita Karlova: Praha, Czech Republic, 1992; pp. 450-455. (In Czech)

75. Krutský, N.; Mag, M.; Radimský, V.; Krones, J.; Cholava, J.; Hubáček, J. Závěrečná Zpráva úkolu Výzkum a Prognózní Zhodnocení Netradičních Nerudních Surovin, Fonolity, 0186 1080; Unpublished; Geoindustria st.p.: Dolby, Czech Republic, 1989; 191p. (In Czech)

76. Ackerman, L.; Ulrych, J.; Ǩanda, Z.; Erban, V.; Hegner, E.; Magna, T.; Balogh, K.; Frána, J.; Lang, M.; Novák, J.K. Geochemical characteristics and petrogenesis of phonolites and trachytic rocks from the České Středohoří Volcanic Complex, the Ohře Rift, Bohemian Massif. Lithos 2015, 224, 256-271. [CrossRef]

77. Kolár̆, Z. Průzkum kamene 1961 Želenice 51331 067; Unpublished; Geologický průzkum, n.p.: Praha, Czech Republic, 1961; 22p. (In Czech)

78. Pazdernik, P. Compositional variations in the sodalite-bearing nephelinite phonolite from Želenický vrch Hill, North Bohemia. Acta Univ. Carol. Geol. 1997, 42, 65-79.

79. Sivek, M.; Kavina, P.; Jirásek, J. New mineral policy of the Czech Republic of June 2017. Resour. Policy 2019, 60, 246-254. [CrossRef]

80. Elsner, H.; Homberg-Heumann, D.; Huy, D.; Lutz, R.; Moldenhauer, K.; Pein, M.; Schauer, M.; Schmidt, S.; Schmitz, M.; Sievers, H.; et al. Deutschland Rohstoffsituation 2018; Bundesanstalt für Geowissenschaften und Rohstoffe: Hannover, Germany, 2019; 144p. (In German)

81. Malon, A. Surowce skaleniowe. In Bilans zasobów złóż kopalin w Polsce wg stanu na 31 XII 2018 r.; Szuflicki, M., Malon, A., Tymiński, M., Eds.; Państwowy Instytut Geologiczny Państwowy Instytut Badawczy: Warszawa, Poland, 2019; pp. 447-448. (In Polish)

82. Lewicka, E. Rational use of selected mining by-products in the ceramic industry in Poland. Gospod. Surowcami Min. 2020, 36, 59-76. [CrossRef]

83. Lewicka, E. Conditions of the feldspathic raw materials supply from domestic and foreign sources in Poland. Gospod. Surowcami Min. 2010, 26, 5-19.

84. Lewicka, E.; Wyszomirski, P. Polish feldspar raw materials for the domestic ceramic tile industry Current state and prospects. Mat. Ceram. 2010, 62, 582-585.

85. Panna, W.; Wyszomirski, P.; Gajek, M. Characteristics of the fine-grained fractions of the crushed Strzegom granites as possible materials in manufacture of ceramic tiles. Gospod. Surowcami Min. 2015, 31, 59-76. [CrossRef]

86. Mayer-Jauck, H.; Schatz, M. Österreichisches Montan-Handbuch 2019; Bundesministerium für Nachhaltigkeit und Tourismus: Wien, Austria, 2019; 345p. (In German)

87. Kúšik, D.; Mižák, J.; Šoltés, S. Slovak Minerals Yearbook 2017; State Geological Institute of Dionyz Stur: Bratislava, Slovakia, 2018; 141p.

(C) 2020 by the authors. Licensee MDPI, Basel, Switzerland. This article is an open access article distributed under the terms and conditions of the Creative Commons Attribution (CC BY) license (http://creativecommons.org/licenses/by/4.0/). 